\title{
Magnetic fabric and rock magnetic studies of metasedimentary rocks in the central Okcheon Metamorphic Belt, Korea
}

\author{
Yong-Hee Park ${ }^{1}$, Seong-Jae Doh ${ }^{1}$, Wonnyon Kim ${ }^{1}$, and Dongwoo Suk ${ }^{2}$ \\ ${ }^{1}$ Department of Earth and Environmental Sciences, Korea University, Seoul 136-713, Korea \\ ${ }^{2}$ Department of Earth and Marine Sciences, Hanyang University, Ansan 425-791, Korea
}

(Received November 29, 2004; Revised June 4, 2005; Accepted June 19, 2005)

\begin{abstract}
Anisotropy of magnetic susceptibility (AMS) and rock magnetic studies have been carried out for the metasedimentary rocks in the central Okcheon Metamorphic Belt. The study area is divided into three metamorphic zones: the biotite zone, the garnet zone, and the sillimanite + andalusite zone from southeast to northwest. Magnetic foliation dipping to the northwest is the dominant magnetic fabric in the biotite zone. Magnetic lineation plunging down-dip of the vertical cleavage plane is appeared in the southeastern part of the garnet zone, while magnetic lineation plunging to southeast prevails in the middle and northwestern parts of the garnet zone. It is interpreted that this apparent synform structure, defined by AMS fabric data, was formed by successive top-to-the-southeast vergent thrusting followed by back-steepening process during the regional metamorphism in the Late Paleozoic. In the sillimanite + andalusite zone, AMS fabric is clearly defined and may reflect a tectonic fabric, recorded during the thermal metamorphism in the middle Jurassic, despite the scarcity of rock fabric in the field. The spatial distribution of magnetic mineralogy, defined by the rock magnetic results, implies the $500^{\circ} \mathrm{C}$ isotherm at the boundary between the biotite and garnet zones, which is associated with the transformation of pyrrhotite into magnetite above $500^{\circ} \mathrm{C}$ under the oxidizing condition.
\end{abstract}

Key words: Magnetic fabric, magnetic mineralogy, metamorphism, Okcheon Belt.

\section{Introduction}

Anisotropy of low field magnetic susceptibility (AMS) studies have been widely used to delineate the petrofabrics of metamorphic rocks in terms of finite strain during tectono-metamorphism (e.g., Graham, 1954; Hrouda, 1982; Borradaile, 1988). The AMS ellipsoid generally reflects composite distribution of grain shapes and preferred crystallographic orientation of the ferromagnetic (sensu lato, s.l.) and paramagnetic minerals (Hrouda, 1982; Borradaile, 1988; Rochette et al., 1992). Although the AMS is a bulk measure of all contribution in a rock, magnetic minerals contributing to the AMS may have crystallized or rearranged at different times with various stress and strain conditions (Borradaile, 1988; Borradaile et al., 1990; Rochette et al., 1992). Therefore, the main magnetic mineralogy and its relation with the measured AMS should be determined for magnetic fabric studies of the metamorphic rocks. On the other hand, several studies showed that magnetic mineralogy can be used as a proxy for the metamorphic zonation in low-grade metamorphosed areas (e.g., Rochette, 1987; Robion et al., 1997). However, it was not verified whether the magnetic zonation can be applied to the medium- and high-grade metamorphosed areas with various lithologies.

The northeast-southwest trending Okcheon (or Ogcheon) Belt is a fold-and-thrust belt which divides the Precambrian basement of the southern Korean Peninsula into the

Copyright (c) The Society of Geomagnetism and Earth, Planetary and Space Sciences (SGEPSS); The Seismological Society of Japan; The Volcanological Society of Japan; The Geodetic Society of Japan; The Japanese Society for Planetary Sciences; TERRAPUB.
Gyeonggi Massif and the Yeongnam Massif (Fig. 1(a)). The Okcheon Belt is composed of southwestern metamorphosed area (Okcheon Metamorphic Belt, OMB) and northeastern non-metamorphosed area (Taebaeksan zone, TZ) (Fig. 1(a)). The OMB consists of non-fossiliferous and low- to high-grade metasediments and metavolcanic rocks, whose ages are not well determined, while the TZ comprises fossiliferous, non-metamorphosed or weakly metamorphosed sedimentary rocks of Paleozoic to Early Mesozoic age (Chough et al., 2000). Generally, the OMB has been suggested as an aborted rift in an intraplate setting based on the bimodal geochemical characteristics of metavolcanic rocks (Cluzel, 1992; Lee et al., 1998). The age of the metasedimentary rocks in the OMB is still obscure but it was postulated as Neoproterozoic or Early Paleozoic (Cho and Kim, 2002). In addition, the structural settings and tectonic evolution of the OMB are not clear yet because of severe deformation of rocks and overprinted structures related to Mesozoic plutonism. From this point of view, new methods such as magnetic fabric and rock magnetic studies are required to examine the deformation processes associated with the metamorphism in the OMB.

In the present study, AMS and rock magnetic studies have been carried out for the metasedimentary rocks in the central OMB in order to reveal the major magnetic fabric and magnetic mineralogy, which had been affected by deformation and metamorphism, in the study area. Another aim of this study is to test whether the magnetic mineralogy can be useful for the metamorphic zonation even in the medium- and high-grade metamorphosed area. 


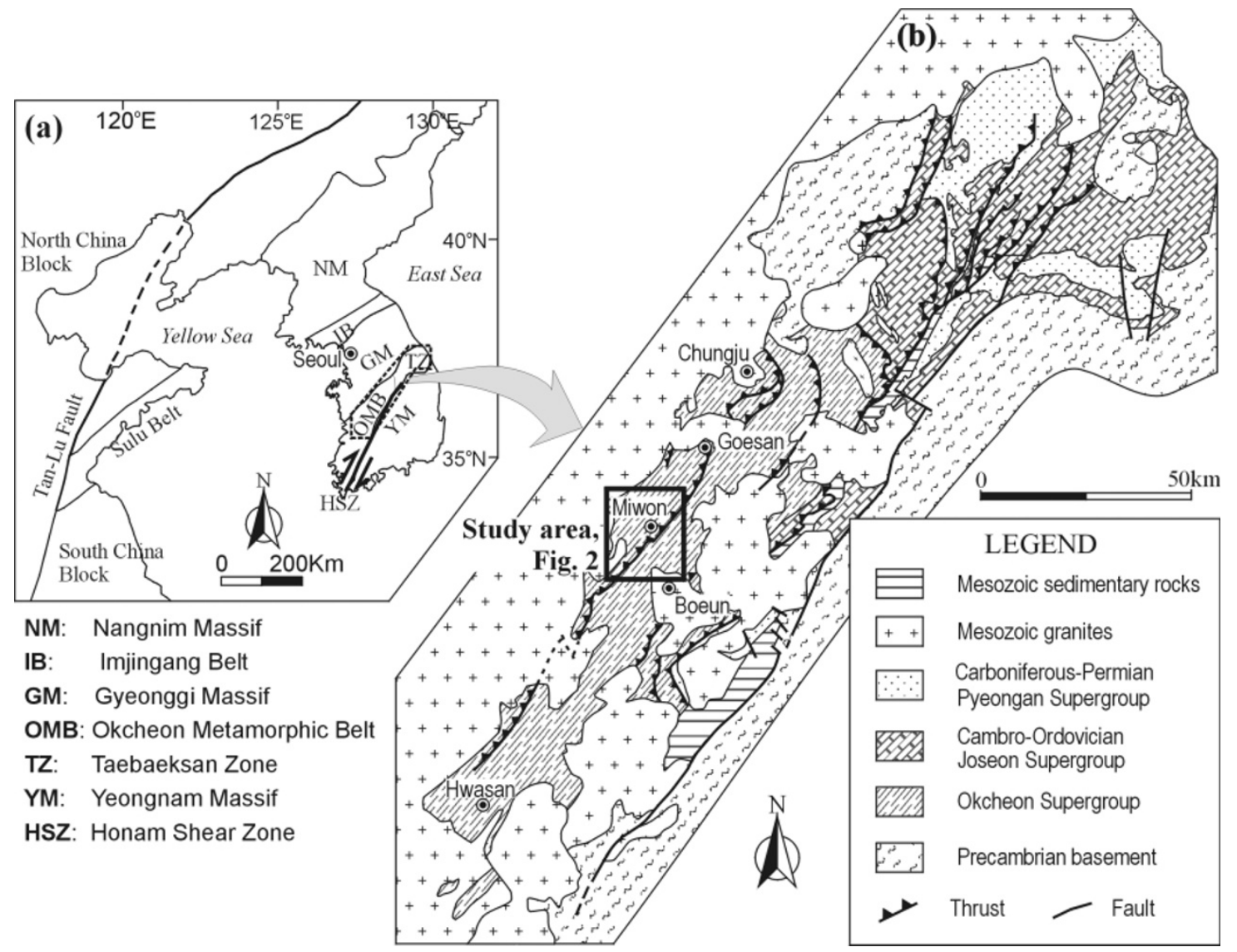

Fig. 1. (a) Simplified tectonic map of East Asia (after Ree et al., 2001) and (b) geologic map of the Okcheon Belt, Korea (modified after Cluzel et al., 1990).

\section{Geological Setting}

The central OMB is mainly composed of pre-Mesozoic (unknown age) metasediments (Okcheon Supergroup) and is intruded by Mesozoic plutonic bodies (Cheongju and Boeun granites) in both northwestern and southeastern parts of the study area (Figs. 1(b) and 2). The Okcheon Supergroup in the study area consists mainly of quartzite (Midongsan Formation), meta-calcareous rocks (Daehyangsan and Hwajeonri formations), meta-psammitic rocks (Ungyori Formation), meta-pelitic rocks (Guryongsan, Hwajeonri, and Munjuri formations), and metaconglomeratic rocks (Iwonri and Hwanggangri formations) with a northeast-southwest-trending zonal distribution (Kim et al., 1977; Lee et al., 1980; Kang and Lee, 2002) (Fig. 2(a)). Stratigraphic relationships in the study area are uncertain because of the scarcity of fossil occurrences and the obliterated primary sedimentary structures by polyphase deformation and metamorphism (Cluzel et al., 1990; Koh and Kim, 1995; Kim and Cho, 1999; Oh et al., 2004). According to the geologic scheme by Cluzel et al. (1990), the study area can be divided into two litho-tectonic units: Pibanryeong unit for the structurally upper unit in the northwest and Boeun unit for the lower unit in the southeast. These units are bounded by thrust faults parallel to the regional trend (i.e., northeast-southwest strike) of the belt (Fig. 2). Although the simplification of Cluzel et al. (1990) has been frequently used in many previous metamorphic petrologic studies (e.g., Kim and Cho, 1999; Oh et al.,
2004), we present the geologic map of Fig. 2(a) that is compiled from 1:50,000 Miwon (Lee et al., 1980) and Boeun (Kim et al., 1977) sheets because the lithology should be considered in interpreting the AMS data.

The study area has experienced at least two metamorphic events (Kim and Cho, 1999; Oh et al., 1999, 2004). Oh et al. (2004) reported that the metamorphic pressure-temperature (P-T) conditions of the first metamorphism $\left(M_{1}\right)$, responsible for the formation of most regional metamorphic mineral assemblages, are $5.4 \sim 9.4 \mathrm{~kb}$ and $520 \sim 635^{\circ} \mathrm{C}$, indicating intermediate $\mathrm{P} / \mathrm{T}$ type regional metamorphism. The metamorphic grade in the study area increases from the southeast (the biotite zone; greenschist facies) toward the northwest (the garnet zone; amphibolite facies) on the basis of the mineral parageneses of metasedimentary rocks (Fig. 2(b)) (Oh et al., 1999, 2004). The typical mineral assemblages are biotite + muscovite + plagioclase + quartz \pm chlorite in the biotite zone and garnet + biotite + muscovite + chlorite + plagioclase + quartz \pm staurolite in the garnet zone (Oh et al., 1999). The $M_{1}$ regional metamorphism occurred during the late Carboniferous to early Permian based on the recent $\mathrm{Pb}-\mathrm{Pb}$ whole rock ages (283-291 Ma) and CHIME (Chemical ThU-total Pb Isochron Method) uranitite ages (281-283 Ma) from black slates in the central OMB (Cheong et al., 2003).

The regional emplacement of Jurassic granite caused low $\mathrm{P} / \mathrm{T}$ thermal metamorphism $\left(M_{2}\right)$, forming sillimanite (fibrolite), andalusite and cordierite in the metasediments 


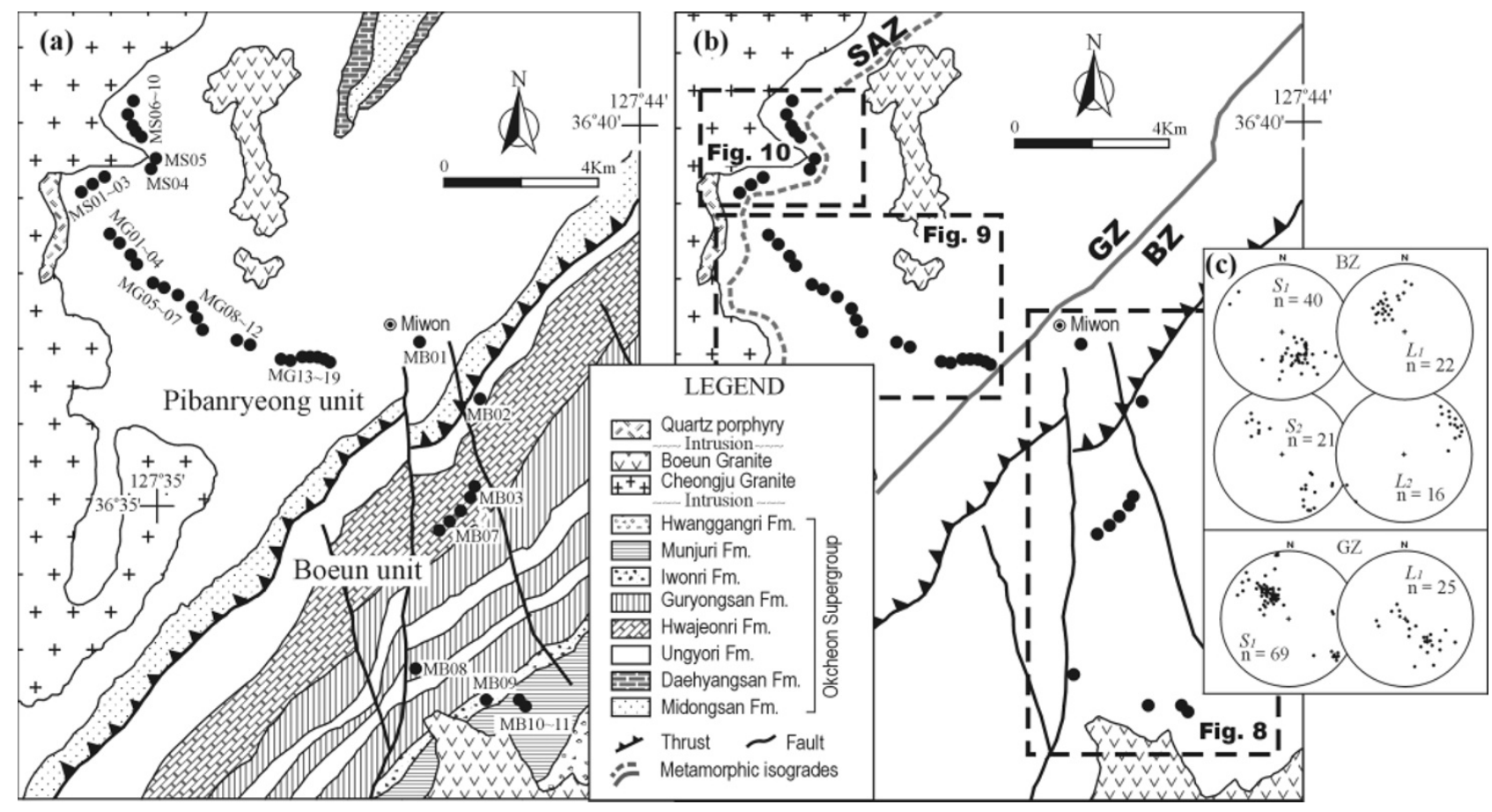

Fig. 2. (a) Geologic and (b) metamorphic map of the central Okcheon Metamorphic Belt, showing sampling sites (after Lee et al., 1980; Oh et al., 1999). (c) Stereoplots of the poles of foliations and the directions of lineations observed in the biotite and garnet zones. Lower-hemisphere equal-area projection.

in the contact aureole (the sillimanite + andalusite zone) around Jurassic granite (Fig. 2(b)). Recent U-Pb zircon and titanite ages (166-178 Ma) on Mesozoic granites indicate that the $M_{2}$ metamorphism occurred during the middle Jurassic (Ree et al., 2001; Oh et al., 2004). The P-T conditions of the $M_{2}$ thermal metamorphism are $2.1 \sim 5.0 \mathrm{~kb}$ and $540 \sim 698^{\circ} \mathrm{C}$ (Oh et al., 1999, 2004). Oh et al. (2004) suggested that the $M_{2}$ low $\mathrm{P} / \mathrm{T}$ regional thermal metamorphism was not intense enough to reset the intermediate $\mathrm{P} / \mathrm{T}$ mineral assemblage formed by $M_{1}$ metamorphism, except in the narrow contact aureole around the granites in the northwestern part of the study area (Fig. 2).

Regional structures of the study area are primarily dominated by large-scale southeast-vergent thrust faults (Fig. 2(a)). Major foliation $\left(S_{1}\right)$ of the study area, defined by cleavage foliation and axial plane foliation of asymmetric isoclinal fold $\left(F_{1}\right)$, generally strikes northeast and dips to the northwest in the biotite zone, but to the southeast in the garnet zone (Fig. 2(c)). A narrow area (sites MB01, MB02, and MG13 MG19) adjacent to the thrust faults shows $S_{1}$ foliations with very steep dip angles $\left(75 \sim 86^{\circ} \mathrm{NW}\right.$ or SE). The metasediments in the biotite zone also show $S_{2}$ foliation, defined by crenulation cleavage formed by microfolding of $S_{1}$ foliation. $S_{2}$ foliation in the biotite zone strikes northeast with relatively steep dip angles $\left(50 \sim 85^{\circ}\right)$ to either northwest or southeast (Fig. 2(c)). $L_{1}$ lineation plunging into dip of $S_{1}$ foliation can be defined by elongated pebbles in the meta-conglomeratic rocks with pelitic matrix (Hwanggangri and Iwonri formations) and by elongated minerals in the meta-pelitic rocks (Munjuri Formation) in the biotite zone. Kang and Lee (2002) reported the eastward or southeastward shear sense of metasedimentary rocks in the biotite zone based on asymmetric isoclinal fold and C-
$\mathrm{S}$ structures. They also interpreted that these foliations $\left(S_{1}\right.$ and $\left.S_{2}\right)$ and their accompanied lineations $\left(L_{1}\right.$ : mineral lineation plunging north to northwest; $L_{2}$ : crenulation or intersection lineation plunging northeast) were mainly formed by dynamic deformations $\left(D_{1}\right.$ : ductile shearing of top-tothe southeast movement; $D_{2}$ : subhorizontal semi-brittle shortening) caused by northwest-southeast compressional event. These $D_{1}$ and $D_{2}$ deformations are regarded as synmetamorphic phases associated with $M_{1}$ regional metamorphism during the late Carboniferous-early Permian (Cluzel et al., 1990, 1991; Cheong et al., 2003; Oh et al., 2004). Petrofabric of massive meta-psammitic schist in the contact aureoles of the Jurassic granite (the sillimanite + andalusite zone) was hardly observed in the field.

\section{Experimental Methods}

A total of 556 oriented samples were collected from 40 sites in the study area: 11 sites from the biotite zone, 19 sites from the garnet zone and 10 sites from the sillimanite+ andalusite zone (Fig. 2(a)). All samples were cored with a gasoline-powered portable rock drill, and were subsequently sliced into $25 \mathrm{~mm}$ diameter and $22 \mathrm{~mm}$ long cylinders in the laboratory.

AMS data for each sample were measured in 12 positions using a Bartington magnetic susceptibility meter (Model MS-2) connected with a MS-2B susceptibility-bridge, and were presented by an ellipsoid with the principal susceptibility axes labeled $K_{\max }>K_{\text {int }}>K_{\min }$. The mean magnetic susceptibility $\left(K_{m}\right)$ for a single sample was given by the arithmetic mean $\left(K_{m}=\left(K_{\max }+K_{\text {int }}+K_{\min }\right) / 3\right.$ in SI units). The magnitude and shape of the susceptibility ellipsoid are expressed by $P_{j}$ (corrected anisotropy degree) and $T$ (symmetry of shape on the vertical axis), respectively, 


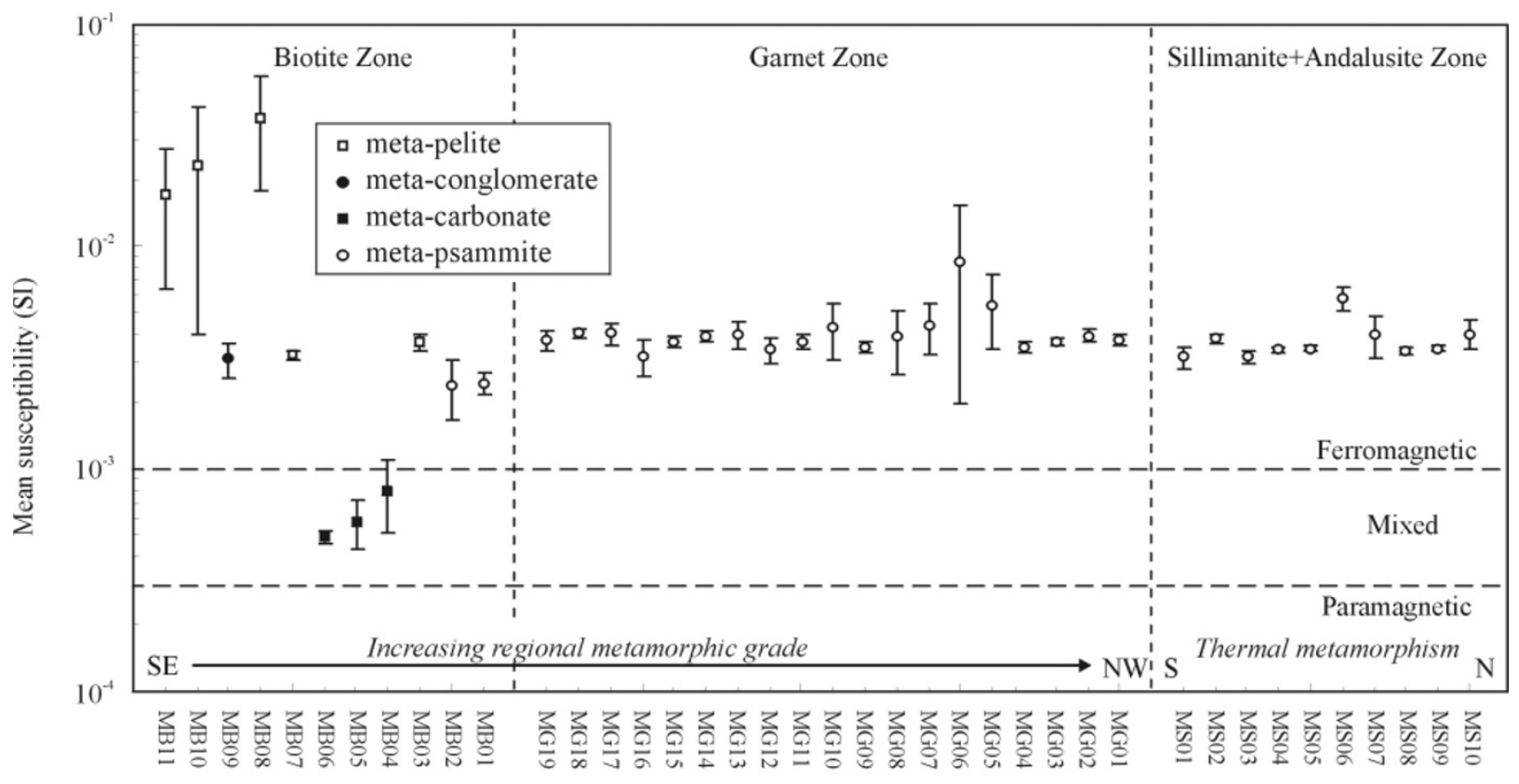

Sampling site

Fig. 3. Plots of mean susceptibilities $\left(K_{m}\right)$ with the standard deviations versus sampling sites in the study area.

proposed by Jelinek (1981):

$$
\begin{aligned}
& P_{j}=\exp \left\{2\left[\left(\eta_{1}-\eta\right)^{2}+\left(\eta_{2}-\eta\right)^{2}+\left(\eta_{3}-\eta\right)^{2}\right]\right\}^{1 / 2} \\
& T=\left[2\left(\eta_{2}-\eta_{3}\right) /\left(\eta_{1}-\eta_{3}\right)\right]-1
\end{aligned}
$$

where $\eta_{1}=\ln K_{\max } ; \eta_{2}=\ln K_{\text {int }} ; \eta_{3}=\ln K_{\min } ; \eta=$ $\left(\eta_{1}+\eta_{2}+\eta_{3}\right) / 3$. The $P_{j}$ parameter is used to quantify the degree of the magnetic anisotropy and $T$ characterizes the shape of the susceptibility ellipsoid (Jelinek, 1981; Hrouda, 1982). To characterize a major magnetic phase in samples, isothermal remanent magnetization (IRM) acquisition experiments were performed by successively exposing selected samples to increasing field of up to $2.5 \mathrm{~T}$ using an ASC Scientific impulse magnetizer (model IM-10-30). We also conducted a stepwise thermal demagnetization of 3axes composite IRM up to $680^{\circ} \mathrm{C}$ (Lowrie, 1990) for selected samples to distinguish both coercivities and unblocking temperatures. IRM was imparted successively at 2.5 $\mathrm{T}, 0.6 \mathrm{~T}$, and $0.1 \mathrm{~T}$ on the $Z-, Y$-, and $X$-axes, respectively, of a sample, and followed by thermal demagnetization using a Magnetic Measurements thermal demagnetizer (model MMTD80). To detect any chemical alteration of magnetic carriers upon heating, magnetic susceptibility was measured at each stage of thermal treatment.

\section{Results}

\subsection{Low-field magnetic susceptibility}

Magnetic susceptibility generally reflects all the effects of diamagnetic, paramagnetic and ferromagnetic (s.l.) minerals but diamagnetism is often negligible with respect to the ferromagnetic and paramagnetic susceptibility. AMS with high values of magnetic susceptibility (e.g., greater than $10^{-3} \mathrm{SI}$ ) is mainly attributed to the ferromagnetic (s.l.) fraction alone, while magnetic susceptibility less than $3 \times 10^{-4}$ SI mainly involves the effect of paramagnetic minerals to the AMS (Rochette et al., 1992; Tarling and Hrouda, 1993; Sagnotti et al., 1998; Kanamatsu et al., 2001). $K_{m}$ values of the metasedimentary rocks from the study area range from $6.9 \times 10^{-2}$ to $3.7 \times 10^{-4}$ SI (Table 1, Fig. 3). Most samples in the study area show $K_{m}$ values above $10^{-3} \mathrm{SI}$, indicating that ferromagnetic minerals (s.l.) mainly contribute to the $K_{m}$ and AMS, except for some samples of meta-carbonates from three sites (MB04, 05, and 06) in the biotite zone (Fig. 3). These samples, showing $K_{m}$ values between $10^{-3}$ and $3 \times 10^{-4}$ SI, indicate both ferromagnetic and paramagnetic fractions contributing to the AMS. Figure 3 shows that $K_{m}$ values from the biotite zone vary in a wide range, whereas those from the garnet and sillimanite + andalusite zones reveal relatively narrow range. The wide range of $K_{m}$ in the biotite zone is attributed to the significant variation of ferromagnetic mineral content in rocks with diverse lithologies (Figs. 2(a) and 3). Meta-pelitic rocks from three sites (MB10 and 11, Munjuri Formation; MB08, Guryongsan Formation) reveal relatively high $K_{m}$ values with wide range than metaconglomerates and meta-psammitic rocks from other sites, indicating that the amount of ferromagnetic (s.l.) fraction in meta-pelitic rocks is higher than that in other lithologies (Fig. 3). On the other hand, meta-carbonates seem to have relatively small amount of ferromagnetic (s.l.) minerals. Samples of meta-psammite, which are most frequently occurred throughout the study area, especially in the garnet and sillimanite + andalusite zones (Fig. 2(a)), do not show a large variation of $K_{m}$ values $\left(10^{-3} \sim 10^{-2} \mathrm{SI}\right)$, indicating that the ferromagnetic (s.l.) concentration in metapsammite is relatively constant (Fig. 3).

\subsection{Magnetic mineralogy}

Stepwise IRM acquisition experiments were conducted to identify major ferromagnetic (s.l.) minerals in the samples. Ferrimagnetic minerals (e.g., magnetite) are usually 
saturated in a field of less than $300 \mathrm{mT}$, while canted antiferromagnetic minerals (e.g., hematite and goethite) require more than $2 \mathrm{~T}$ to be saturated (Butler, 1992). Although monoclinic pyrrhotite $\left(\mathrm{Fe}_{7} \mathrm{~S}_{8}\right)$ is a ferrimagnetic mineral, single domain (SD) or pseudo-single domain (PSD) pyrrhotite generally shows a continuous increase in IRM intensity at relatively high field $(0.3 \sim 2.7 \mathrm{~T}$ ) (Rochette et al., 2001). IRM acquisition patterns can be grouped into three types (Fig. 4). Type 1 shows the rapid acquisition of IRM in a field of less than $100 \mathrm{mT}$ and reaching more than $90 \%$ saturation at about $500 \mathrm{mT}$ (Fig. 4(a)). This behavior suggests that the ferrimagnetic minerals are a major contributor to the magnetization. Samples of type 2 reach $60 \sim 80 \%$ saturation at $300 \mathrm{mT}$ and then followed by gradual acquisition of additional IRM up to $2.5 \mathrm{~T}$ (Fig. 4(b)). This behavior is indicative either of the mixture of ferrimagnetic and canted antiferromagnetic materials or of the presence of high coercivity SD/PSD pyrrhotite. In case of type 3, a gradual acquisition of IRM up to the maximum magnetizing field of $2.5 \mathrm{~T}$ suggests that canted antiferromagnetic minerals make an important contribution to the IRM acquisition possibly with a partial effect of SD/PSD pyrrhotite (Fig. 4(c)).

The stepwise thermal demagnetization of 3-axes composite IRM was performed on at least one sample per site to distinguish both coercivity spectra and unblocking temperature behaviors (Fig. 5). No significant alteration of magnetic carriers was observed during thermal treatment based on constant magnetic susceptibilities. Ferrimagnetic dominant samples (type 1, Fig. 4(a)) identified by IRM acquisition experiments can be divided into three phases according to magnetic mineralogy: the removal of softcoercivity component below $350^{\circ} \mathrm{C}$, indicating the presence of pyrrhotite (Fig. 5(a)); the soft-coercivity component with maximum unblocking temperatures up to $580^{\circ} \mathrm{C}$ attributed to the magnetite (Fig. 5(b)); and the coexistence of pyrrhotite and magnetite (Fig. 5(c)). Most samples from the biotite zone show the pyrrhotite-dominant phase, while magnetite-dominant phase and the mixture of pyrrhotite and magnetite are most frequently observed in the garnet zone and the sillimanite + andalusite zone. Samples corresponding to type 2 of IRM acquisition behavior generally reveal both the soft- to medium-coercivities, attributed to pyrrhotite and magnetite, and the hard-coercivity component with maximum unblocking temperatures up to $680^{\circ} \mathrm{C}$ carried by hematite (Fig. 5(d)). However, a few samples showing type 2 of IRM acquisition pattern (i.e., MG07-5 and MS03-6 in Fig. 4(b)) have the mixture of pyrrhotite and magnetite without hematite (Fig. 6(e)), which is attributed to the effect of high coercivity SD/PSD pyrrhotite (Rochette et al., 2001). Samples belonging to type 3 of IRM acquisition behavior show that hematite is the major magnetic carrier, based on the distinctive medium- to hard-coercivities with maximum unblocking temperatures of $680^{\circ} \mathrm{C}$, with small amount of magnetite (Fig. 5(f)) or pyrrhotite (Fig. 5(g)). The hematite-dominant samples occur from only five sites (Fig. 4(c)). In addition to these magnetic minerals (pyrrhotite, magnetite, and hematite), goethite showing the hard coercivity component with low maximum unblocking temperatures of ca. $120^{\circ} \mathrm{C}$ is un-

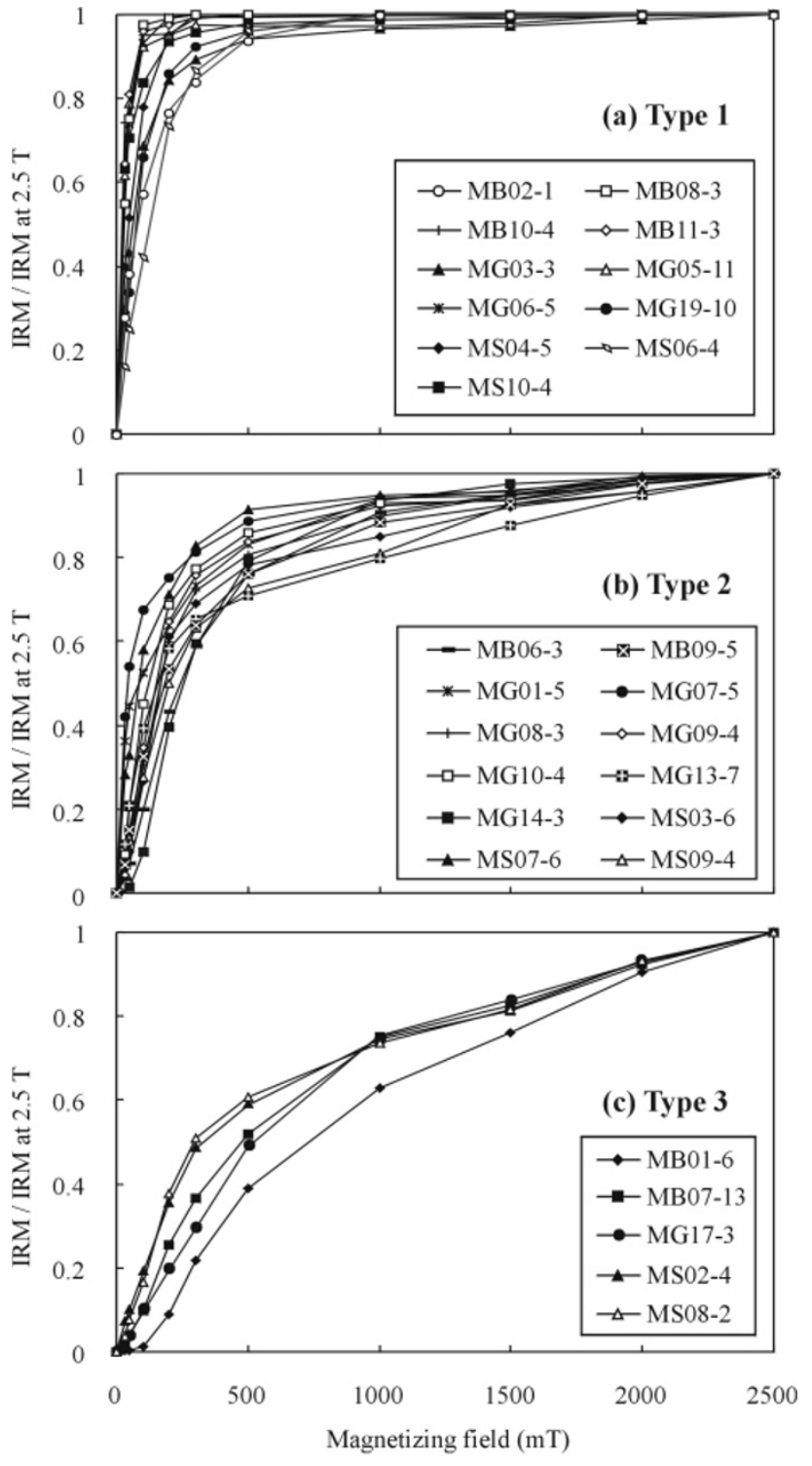

Fig. 4. Representative isothermal remanent magnetization (IRM) acquisition curves for each site.

commonly recognized from samples of three sites (MB01, MG18, and MS08) (Fig. 5(h)). Based on the results of thermal demagnetization of 3-axes IRMs experiments, the magnetic mineralogy in the study area can be roughly outlined. Pyrrhotite is the most abundant magnetic carrier of rocks in the biotite zone, in spite of its various lithologies (i.e., meta-carbonate, meta-pelite, meta-conglomerate, and metapsammite), while the mixture of pyrrhotite and magnetite is frequently observed from the meta-psammite in the garnet and sillimanite + andalusite zones. Hematite and goethite are the relatively minor magnetic phases throughout the study area. Thus, the magnetic mineralogy in samples of the study area is apparently controlled by metamorphic grade, as well as the lithology of rocks, based on the occurrence of magnetite in more highly metamorphosed area. The relationship between magnetic mineralogy and metamorphic grade will be further discussed in Section 5.1. 


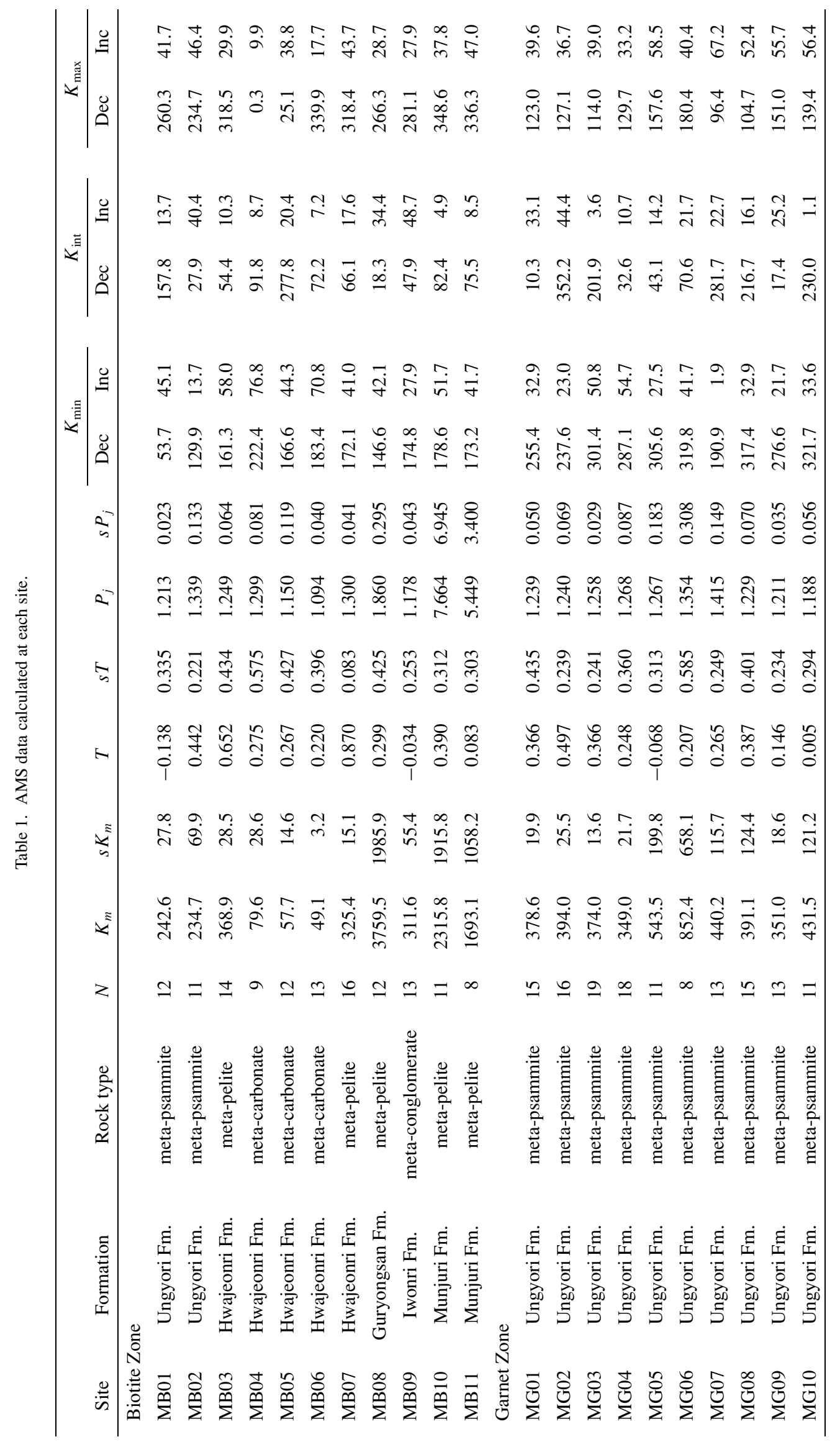




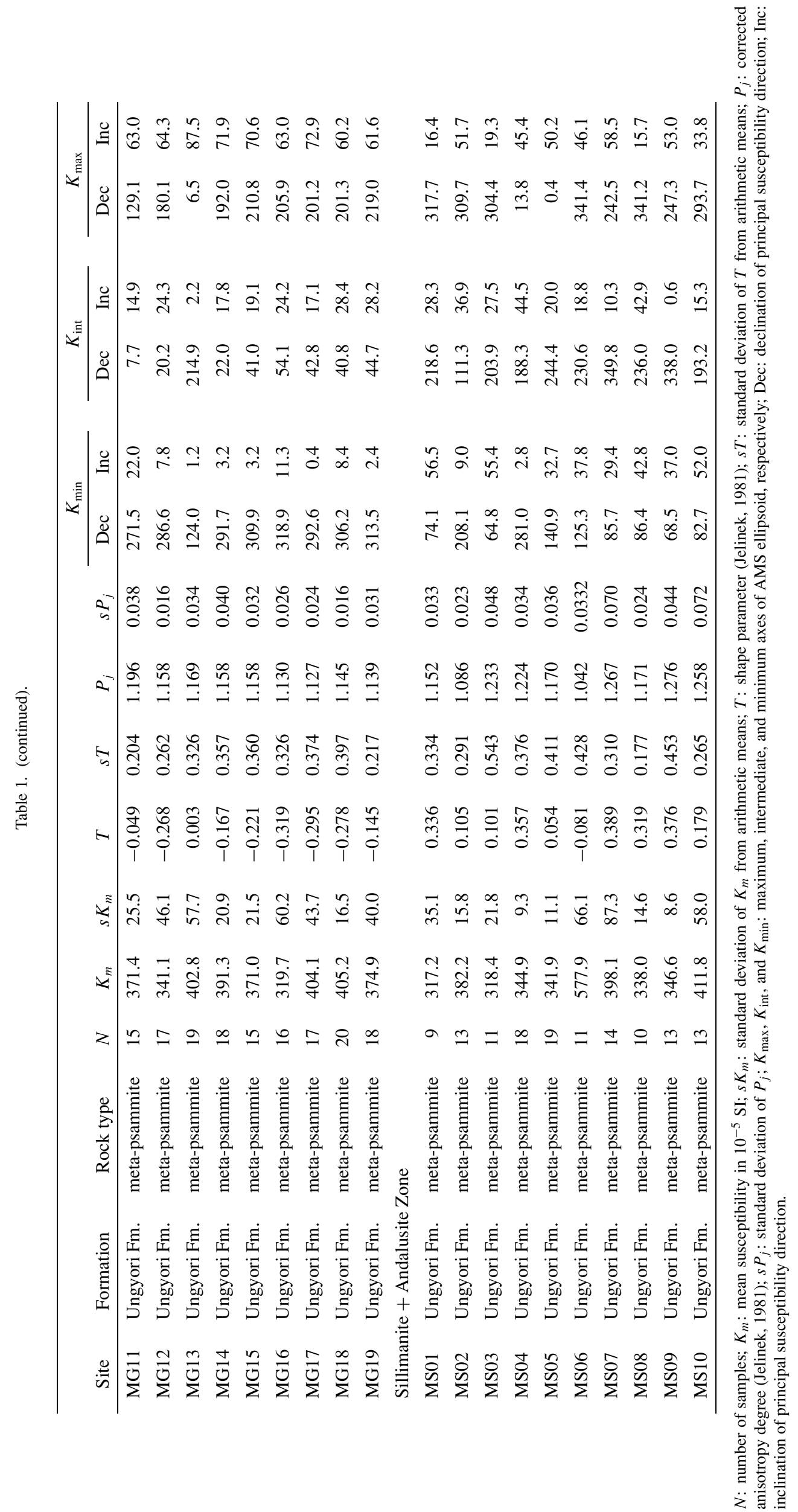



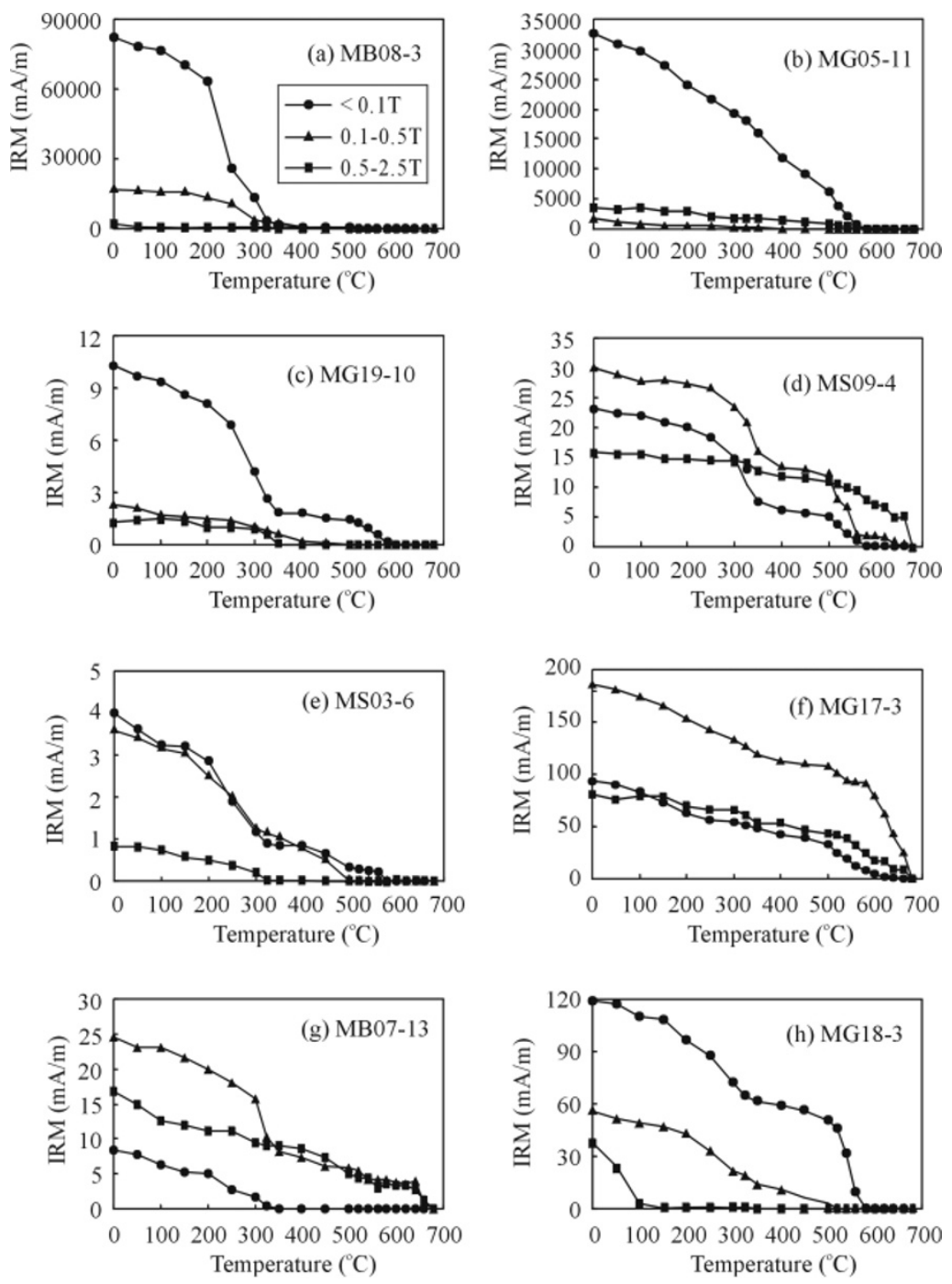

Fig. 5. Thermal demagnetization results of 3-axes composite IRM for the representative samples.

\subsection{AMS parameters}

A relationship between the mean susceptibility $\left(K_{m}\right)$ and the degree of anisotropy $\left(P_{j}\right)$ of samples from the study area is plotted on Fig. 6 and shows some positive correlation on a large scale. Samples with various lithologies from the biotite zone show wide range of $K_{m}$ and $P_{j}$ values, while those of meta-psammites from the garnet zone and the sillimanite + andalusite zone reveal relatively small variation of $K_{m}$ and $P_{j}$. This result seemingly indicates that the variation of $K_{m}$ and $P_{j}$ values is associated with rock type in this study. The extremely large variations of $P_{j}$ for meta-pelites in the biotite zone can be explained by variable content of pyrrhotite in samples (Fig. 6(a)), considering that pyrrhotite, a major magnetic phase in the biotite zone, has a much stronger intrinsic crystallographic anisotropy than magnetite or phyllosilicates (Hrouda, 1982; Rochette, 1987). Samples of meta-carbonates (sites MB04, 05 , and 06) show relatively low values of $K_{m}$ and $P_{j}$, which may reflect the fact that calcite is diamagnetic with low values of susceptibility and/or that the content and anisotropic ratios of ferromagnetic (s.l.) mineral in samples of calcareous rocks are relatively lower than those of other lithologies (Fig. 6(a)). The $K_{m}$ and $P_{j}$ values of meta-psammites in the study area were compared to determine the relationship between these parameters and metamorphic grade. It is shown that $K_{m}$ and $P_{j}$ values in the highly metamorphosed garnet zone are more or less higher than those in the biotite zone (Figs. 6(a) and (b)). This result from the meta-psammites implies that the anisotropic ratios and content of ferromagnetic (s.l.) minerals increased as metamorphic grade increased in the study area. This interpretation is possibly attributed to alterations of pre-existing magnetic minerals or phyllosilicates into new magnetic carriers under a higher metamorphic condition. For instance, pyrrhotite can form by the reduction of pyrite or breakdown of detrital magnetite as the temperature increases (ca. $250^{\circ} \mathrm{C}$ ) under the reducing condition during progressive regional metamorphism (e.g., Ferry, 1981; Rochette, 1987; Robion et al., 1997). The small variation of $K_{m}$ and relatively low $P_{j}$ values from the sillimanite + andalusite zone might be explained by the formation of new magnetic minerals having a weak anisotropy due to the thermal metamorphism (Fig. 6(c)).

$T-P_{j}$ plots (Jelinek, 1981) for each metamorphic zone show some characteristics according to the metamorphic grade (Fig. 7). Samples showing positive $T$ values cor- 


\section{(a) Biotite Zone}

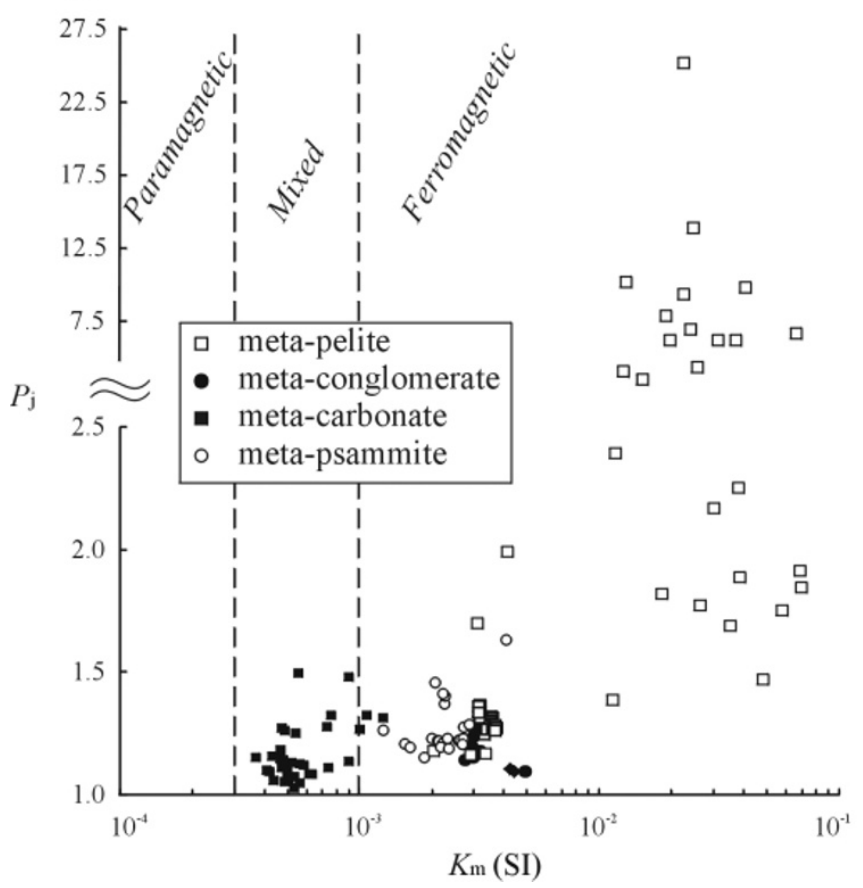

(b) Garnet Zone

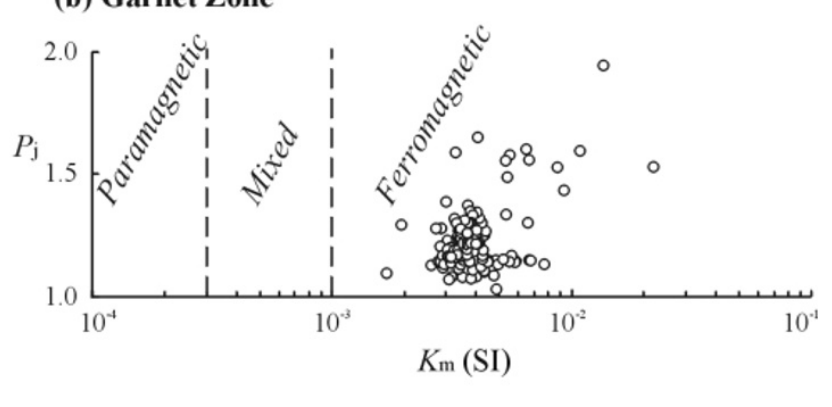

(c) Sillimanite+Andalusite Zone

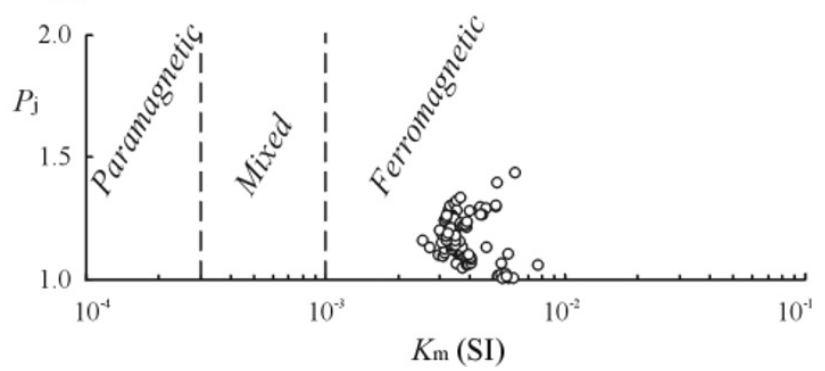

Fig. 6. Plots of degree of anisotropy $\left(P_{j}\right.$, after Jelinek, 1981) versus mean susceptibilities $\left(K_{m}\right)$ of samples from (a) the biotite zone, (b) the garnet zone, and (c) the sillimanite + andalusite zone.
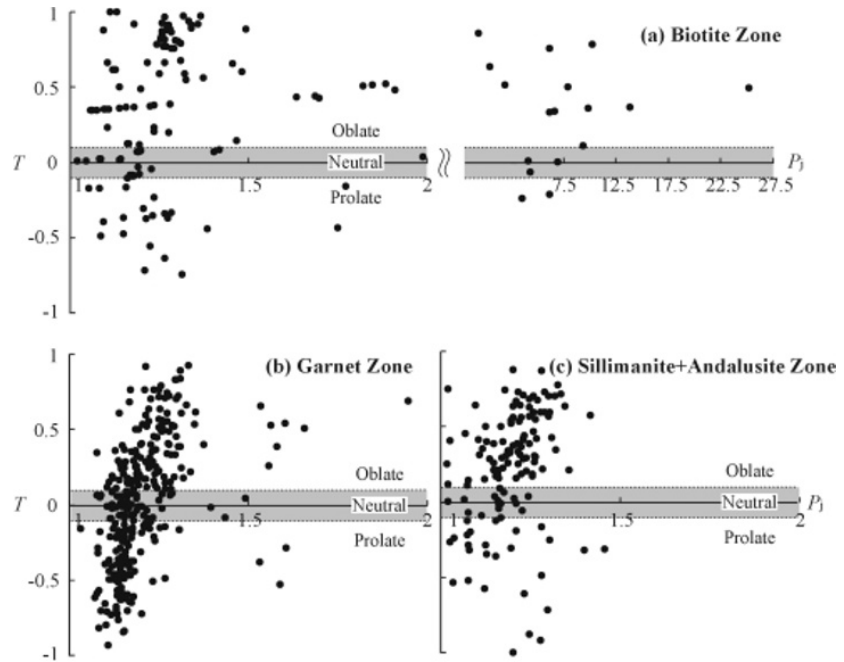

Fig. 7. $T-P_{j}$ diagram (Jelinek, 1981) in (a) the biotite zone, (b) the garnet zone, and (c) the sillimanite + andalusite zone.

responding to oblate fabrics with a wide range of $P_{j}$ at high values, attributed to pyrrhotite, are more frequently observed in the biotite zone (Fig. 7(a)), while samples with a wide range of $T$ and relatively low $P_{j}$ values are dominant in the garnet zone (Fig. 7(b)). These results indicate that the contribution of pyrrhotite to AMS in the more intensively metamorphosed garnet zone, where the only metapsammite occurs, is smaller than that in the less intensively metamorphosed biotite zone having various lithologies. Rocks from the sillimanite + andalusite zone, affected by thermal metamorphism, show similar pattern of $T$ and $P_{j}$ values to that of the garnet zone (Fig. 3(c)).

\subsection{Magnetic fabric}

Mean directions of the principal axes of AMS ellipsoids for each site are listed in Table 1. Principal axes of AMS ellipsoids in most sites of this study are clustered and are indicative of well-defined magnetic fabrics (Figs. 8, 9, and 10). The magnetic fabric in the biotite zone is characterized by magnetic foliations which show a good agreement with the cleavages observed in the field (Fig. 8). Sites MB09 and MB11 located in the southern part of the biotite zone reveal that the anisotropy ellipsoids are triaxial with the $K_{\min }$ axes sub-parallel to the pole of cleavage plane and the $K_{\max }$ axes sub-parallel to cleavage strike (MB09) or oriented downdip in the cleavage plane (MB11). The other sites, except for site MB01, show more oblate magnetic fabrics with the $K_{\min }$ axes sub-parallel to the cleavage pole and the $K_{\max }$ and $K_{\text {int }}$ axes distributed in a girdle within the plane of the $S_{1}$ foliation. The $K_{\min }$ axes of sites MB04, 05, and 06, whose $K_{m}$ values are relatively low (Table 1, Fig. 3), are more or less dispersed (Fig. 8). It is possibly attributed to a complex contribution of diamagnetic, paramagnetic and ferromagnetic (s.l.) minerals to the AMS fabrics, an effect of other foliations unrecognized in the field, and/or small $K_{m}$ values. Magnetic foliations in the biotite zone are well matched with $S_{1}$ foliation (slaty cleavage and axial plane foliation of asymmetric isoclinal fold) rather than with $S_{2}$ foliation (crenulation foliation). Site MB01, which is located north of the thrust faults, has a magnetic lineation with the $K_{\max }$ axes toward down-dip in the cleavage plane and the $K_{\text {int }}$ and $K_{\min }$ axes distributed in a girdle, and shows a different feature of magnetic fabric from the other sites located south of the thrust faults in the biotite zone.

The principal axes of AMS ellipsoids in the garnet zone are characterized by magnetic lineations, which show well- 


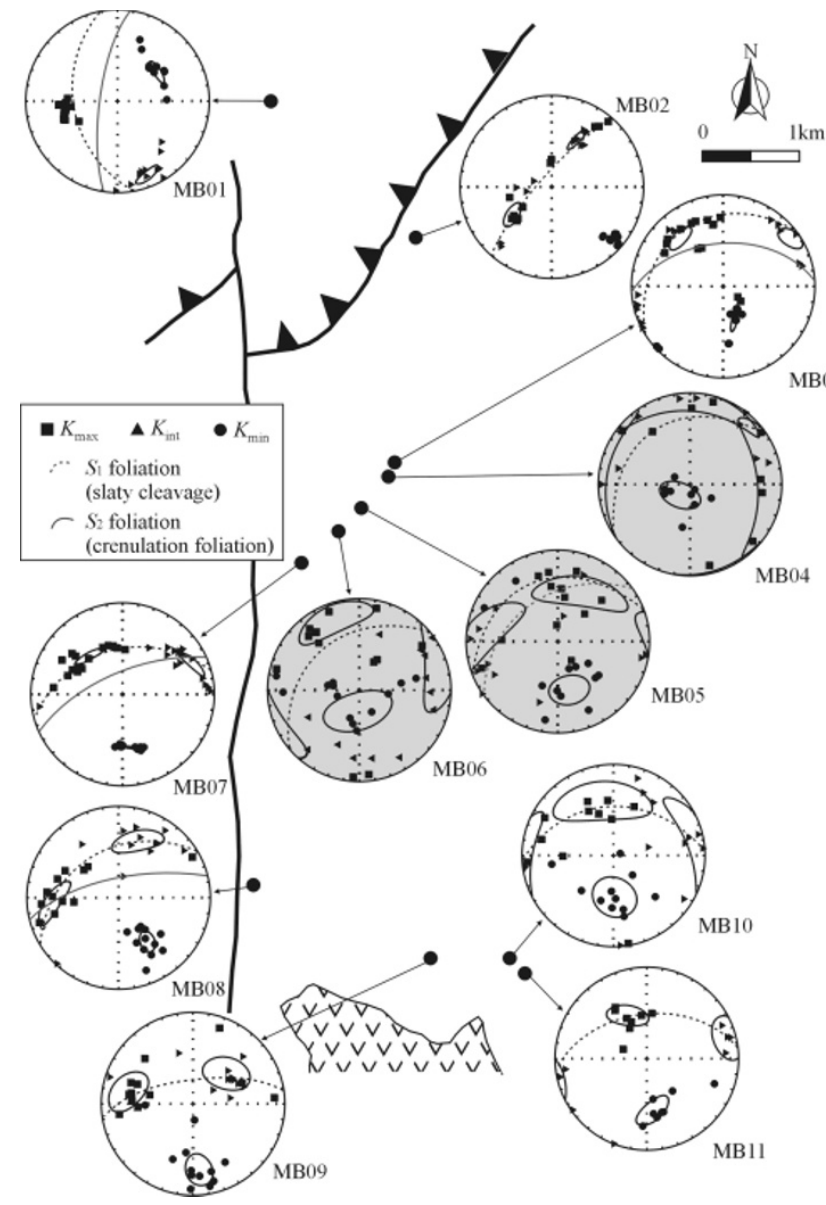

Fig. 8. AMS results from the biotite zone. Orientations of the principal susceptibility axes are plotted on lower-hemisphere equal area projection. Gray hemispheres are from sites showing relatively low $K_{m}$ values. The planes of $S_{1}$ and $S_{2}$ foliations, which were measured from the outcrops in the field, are also shown as dotted and solid curves, respectively.

grouped $K_{\max }$ axes directions with the $K_{\min }$ axes normal to the cleavage (e.g., site MG14) or the girdle distribution of the $K_{\min }$ and $K_{\text {int }}$ axes (e.g., site MG01) (Fig. 9). Magnetic lineation directions in the southeastern part (sites MG13 MG19) of the garnet zone are plunging downdip but slightly biased toward the southwest, except for site MG13, within the northeast-striking vertical cleavage plane. Magnetic lineations plunging to the down-dip direction of northeast- to east-striking cleavage with the moderate to steep dip angle are frequently observed in the middle part of the garnet zone (sites MG05 MG12), whereas in the northwestern part (sites MG01 MG04) magnetic lineations oriented in between the down-dip and strike directions of cleavage. However, most magnetic lineation directions, plunging to the southeast, in the middle and northwestern parts are well-grouped and coincident with those of the mineral stretching lineations when they are observed. In addition to the magnetic lineation, the magnetic foliations, subparallel to the cleavage plane, are frequently observed in the garnet zone (e.g., sites MG04, 06, 08, 09, 13, 14, 15, 18, and 19 in Fig. 9).

In the sillimanite + andalusite zone, the AMS method is particularly more effective than conventional structural methods because the outcrops of massive meta-psammitic schist have no mesoscopic structures in the field. AMS fabrics of the sillimanite + andalusite zone, located close to the Jurassic Cheongju granite, show well-grouped $K_{\text {min }}$ axes and can be divided into two categories according to the distribution of $K_{\max }$ and $K_{\text {int }}$ axes (Fig. 10): the planar fabric in the northern part (sites MS06 MS10) and the triaxial fabric in the southern part (sites MS01 MS05). The planar fabric indicates the magnetic foliation dipping to the west, while the triaxial fabric generally denotes, in addition to the magnetic foliation, the magnetic lineation plunging to the north (sites MS04 and 05) or northwest (MS01, 02, and 03). It is unclear what caused the magnetic fabrics of different type between the northern and southern parts at present. On the other hand, dip directions of magnetic foliation in the sillimanite + andalusite zone are nearly opposite to those in the northwestern part of the garnet zone (sites MG01 MG04). It is interpreted that this attitudinal discrepancy of the magnetic foliations between the two metamorphic zones might reflect the effect of thermal metamorphism in the sillimanite + andalusite zone. In other words, the emplacement of Jurassic granite in the northwest of the study area gave rise to reset pre-existing rock fabrics recorded during the $M_{1}$ regional metamorphism, and to form new magnetic minerals with a certain preferred orientation reflecting the prevailing strain condition during the $M_{2}$ contact metamorphism. However, it certainly requires more detailed studies, including traditional strain methods, on the meta-psammite in the sillimanite-andalusite zone to confirm the interpretation in this study.

\section{Discussion and Conclusions}

\subsection{Magnetic mineralogy, AMS parameters, and meta- morphic zonation}

The predominant ferromagnetic (s.l.) mineral assemblages for each metamorphic zone were outlined based on the results of rock magnetic experiments (Figs. 4, 5, and 11). Figure 11, summary of the $P_{j}, T$, lithology, magnetic mineralogy, and $K_{m}$ versus sampling sites, shows that pyrrhotite is the dominant magnetic mineral throughout the study area and is often accompanied by magnetite, hematite, and rarely goethite. It is known that pyrrhotite or magnetite can be crystallized under the metamorphic conditions of greenschist facies and amphibolite facies, and that their content generally increases as metamorphic grade increases (Tarling and Hrouda, 1993; Borradaile and Henry, 1997). The metasedimentary rocks of the biotite zone, the lowest metamorphosed zone in the study area, show the greenschist facies metamorphic condition (Oh et al., 1999). In addition, the AMS fabrics observed in the present study are not the sedimentary fabric but the tectonic one. Therefore, it is assumed that pyrrhotite occurred in the study area responsible for the observed AMS fabrics is of metamorphic origin. Several studies described the formation of pyrrhotite associated with metamorphic evolution. Ferry (1981) reported that the amount of pyrrhotite showed a positive correlation with the temperature during low-grade metamorphism. Rochette (1987) showed that the increase of metamorphic grade would coincide with the breakdown of detrital magnetite into pyrrhotite in black shale. Ro- 


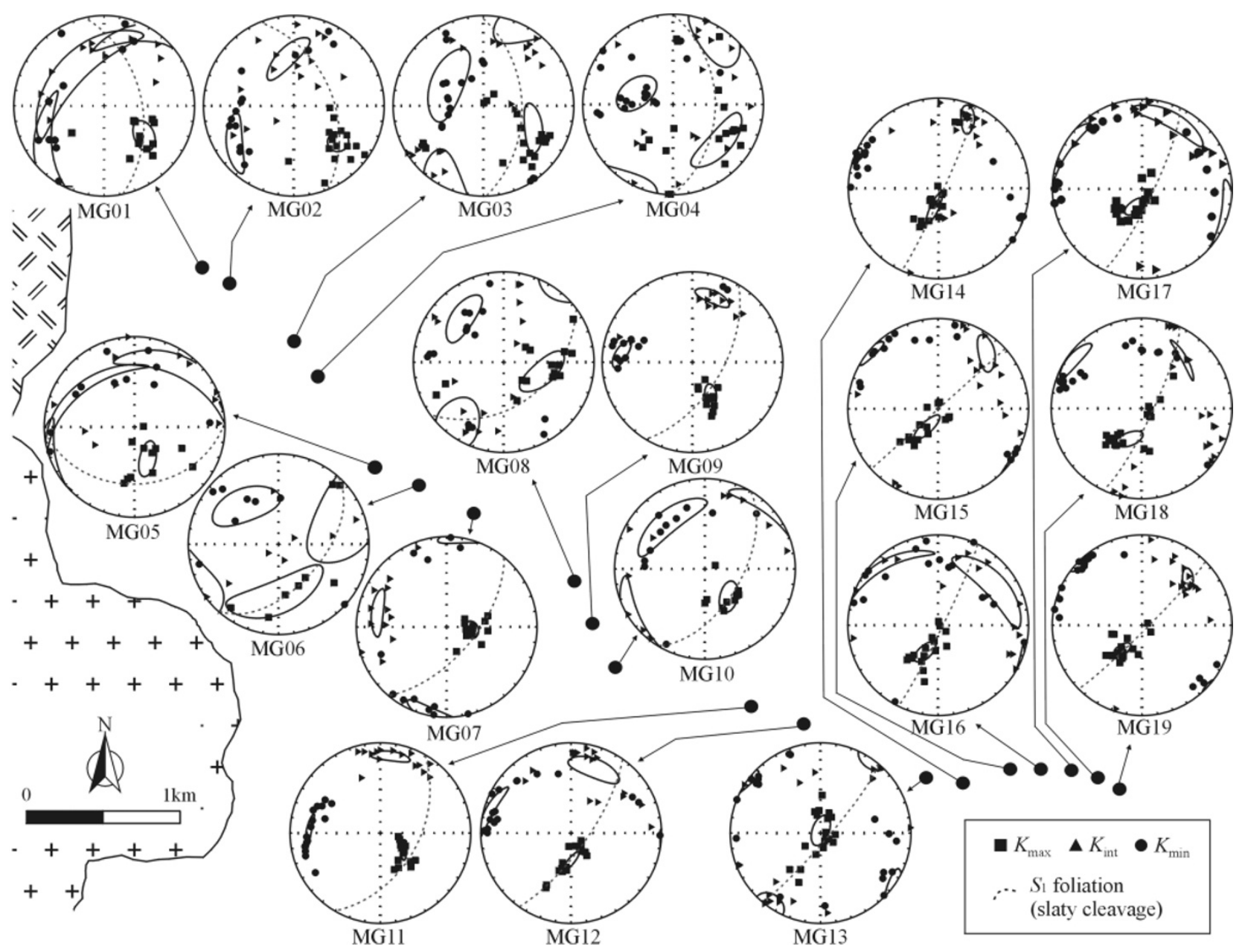

Fig. 9. AMS results from the garnet zone.

bion et al. (1997) suggested that the maximum concentration of pyrrhotite in rocks, identified by peak values of lowfield and anhysteretic susceptibilities, would represent the apex of an earlier prograde metamorphic development prior to the later retrograde metamorphism associated with the Variscan shortening event in the French Ardennes Massif. Although pyrrhotite occurred in the study area seems related to the metamorphic evolution, its concentration is also strongly controlled by lithology. Extremely high $K_{m}$ values are present in meta-pelitic rocks (sites MB08, 10, and 11 ), whereas very low $K_{m}$ values appear in meta-carbonates (sites MB04, 05, and 06) (Fig. 11). This result can be attributed to the concentration variation of pyrrhotite according to rock type, indicating that the $K_{m}$ values cannot directly reflect the metamorphic grade in case of this study area where various lithologies present. Therefore, the relationship between metamorphic grade and magnetic mineralogy or $K_{m}$ values should be determined only for the selected sites of the same lithology. It is worth noting that magnetite within meta-psammitic sites begins to appear from the southeastern part of the garnet zone (site MG19) to the high-grade metamorphic zone (Fig. 11). Two sites (MB01 and 02) of meta-psammite in the biotite zone do not show any signature of magnetite during the rock magnetic experiments. Bina et al. (1991) and Bina and Daly (1994) reported the breakdown of pyrrhotite into magnetite above $500^{\circ} \mathrm{C}$ during heating under the oxidizing condition in the laboratory. In addition, the peak P-T conditions of the biotite zone and the garnet zone have been previously reported as 3.6 4.4 $\mathrm{kb}$ and $350 \sim 450^{\circ} \mathrm{C}$ (Kim et al., 2002) and $5.4 \sim 9.4 \mathrm{~kb}$ and $520 \sim 635^{\circ} \mathrm{C}$ (Oh et al., 2004), respectively. Thus, it is interpreted that magnetite is of metamorphic origin and the occurrence of magnetite in the garnet and sillimanite + andalusite zones probably represents the transformation of pyrrhotite into magnetite above $500^{\circ} \mathrm{C}$ under the oxidizing condition, and that the boundary between the biotite and garnet zones possibly delimits the $500^{\circ} \mathrm{C}$ isotherm.

In this study, $K_{m}$ values of meta-psammite from the garnet and sillimanite + andalusite zones are slightly higher than those from the biotite zone (Fig. 11). In metapsammitic rocks throughout the study area, ferromagnetic minerals mainly contribute to AMS as discussed in Section 4.1. Thus, the increase of $K_{m}$ values possibly reflects the increase of ferromagnetic mineral concentration, as well as the variation of ferromagnetic mineralogy (i.e., transformation of pyrrhotite into magnetite), associated with the increase of metamorphic grade.

It is worth noting that it is possible to detect the gradual increase of $T$ values from negative (prolate ellipsoid) to positive (oblate ellipsoid) as the metamorphic grade increases (dashed arrow in Fig. 11) in meta-psammitic rocks. 


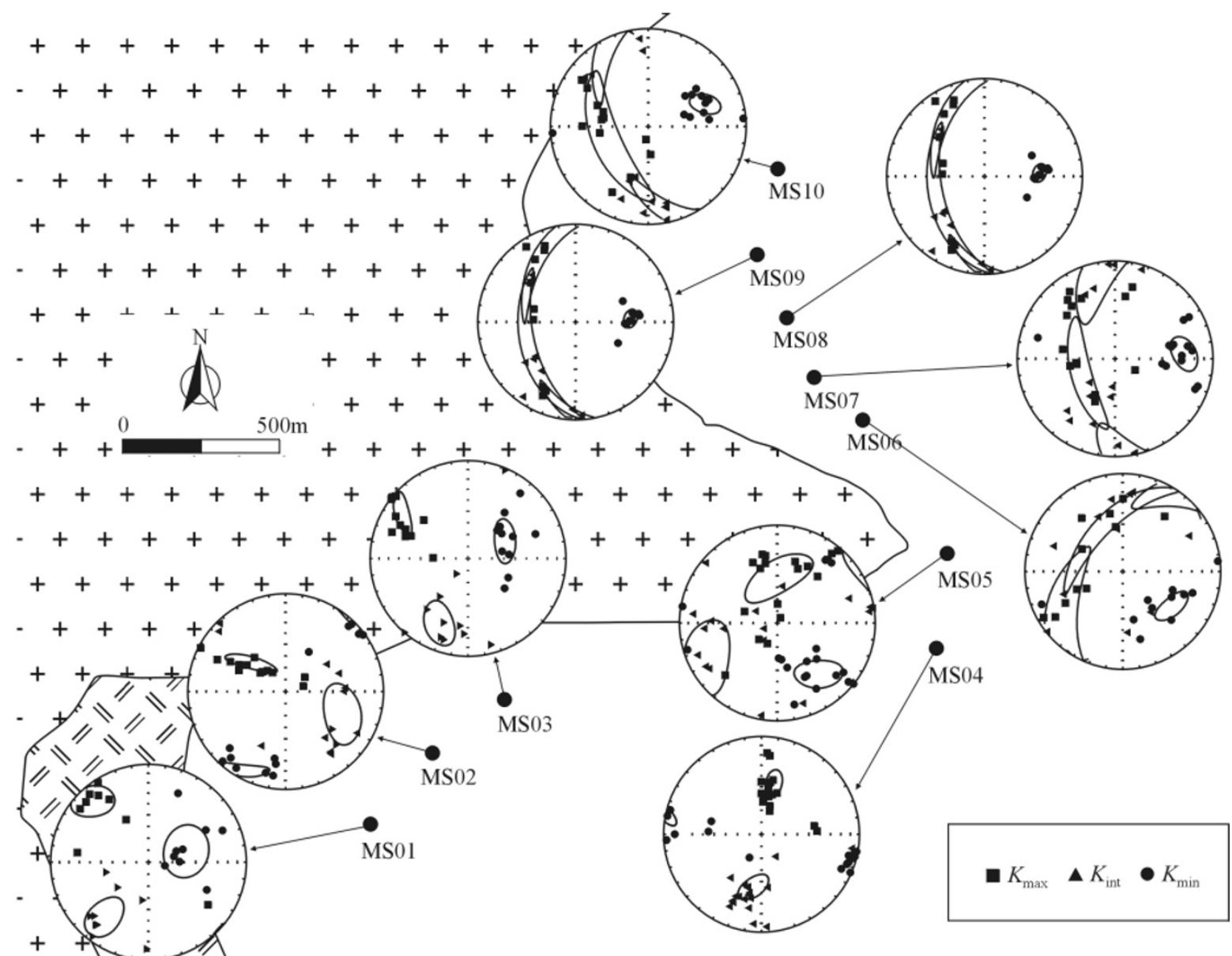

Fig. 10. AMS results from the sillimanite + andalusite zone.

The more prolate ellipsoids $(T<0)$ in the southeastern part of the garnet zone are apparently related to the increasing contribution of magnetite to the AMS fabrics (Fig. 11). Magnetite generally crystallizes and grows with an equidimensional shape because of its isotropic crystallography. However, even slightly irregular magnetite grains can have a strong magnetic anisotropy due to the strong magnetic susceptibility anisotropy of magnetite crystals (Evans et al., 2003). Strain regime during the tectonometamorphism might enhance the linear anisotropy of magnetite. A susceptibility anisotropy of magnetite also arises if magnetically-interacting, equidimensional magnetite particles are located preferentially along planes or lines such as cleavages of mafic silicates (preferred location fabrics, Fuller, 1963; Hargraves et al., 1991; Stephenson, 1993; Grégoire et al., 1995; Borradaile and Henry, 1997). On the other hand, the anisotropy of pyrrhotite in the metamorphic rocks can be explained by a strain-induced grainalignment of polycrystalline aggregates or by a stresscontrolled crystallization (Borradaile and Henry, 1997). The linear anisotropy of pyrrhotite can be also resulted from crystallographic alignment of grains formed as a new phase within the cleavage (Robion et al., 1995). Borradaile and Henry (1997) reported a slight fabric contrast, more disklike fabric $(T>0$, oblate) to more neutral shape $(T \approx 0)$, as the metamorphic grade increases from greenschist facies to amphibolite facies, and they attributed this observation to the growth of biotite at the expense of polycrystalline pyrrhotite. However, what is observed in this study is rather reversed changes in magnetic fabrics of more prolate ellipsoid $(T<0)$ to more neutral $(T \approx 0)$ even to oblate ellipsoid $(T>0)$ as the metamorphic grade increases. In addition, the mean susceptibility $\left(K_{m}\right)$ noticeably neither decreases as for the case of growth of silicate minerals at the expense of pyrrhotite (Borradaile and Henry, 1997) nor increases as a result of transformation of pyrrhotite into magnetite as the metamorphism increases, except for sites MG05 and MG06 for which the increases in $K_{m}$ values coincide with the decreases in $T$ values (Fig. 11). A small variation of $K_{m}$ values requires either a similar proportion of magnetite and pyrrhotite or a decrease of magnetite content accompanied by an increase of pyrrhotite content at a proper ratio because magnetite has a larger susceptibility value than pyrrhotite. The changes of AMS ellipsoid from prolate to neutral and even to oblate shape necessitate the more contribution of pyrrhotite, which has more intrinsic oblate crystallographic anisotropy relative to magnetite, to the observed AMS fabrics. An increasing contribution of pyrrhotite is one of the most plausible explanations to the observation of $T$ and $K_{m}$ values in this study as the metamorphic grade increases. Thus, it can be hypothesized that the more prolate ellipsoids $(T<0)$ in the southeastern part of the garnet zone (Fig. 11) can be attributed to the influence of newly formed magnetite, while the more neutral 


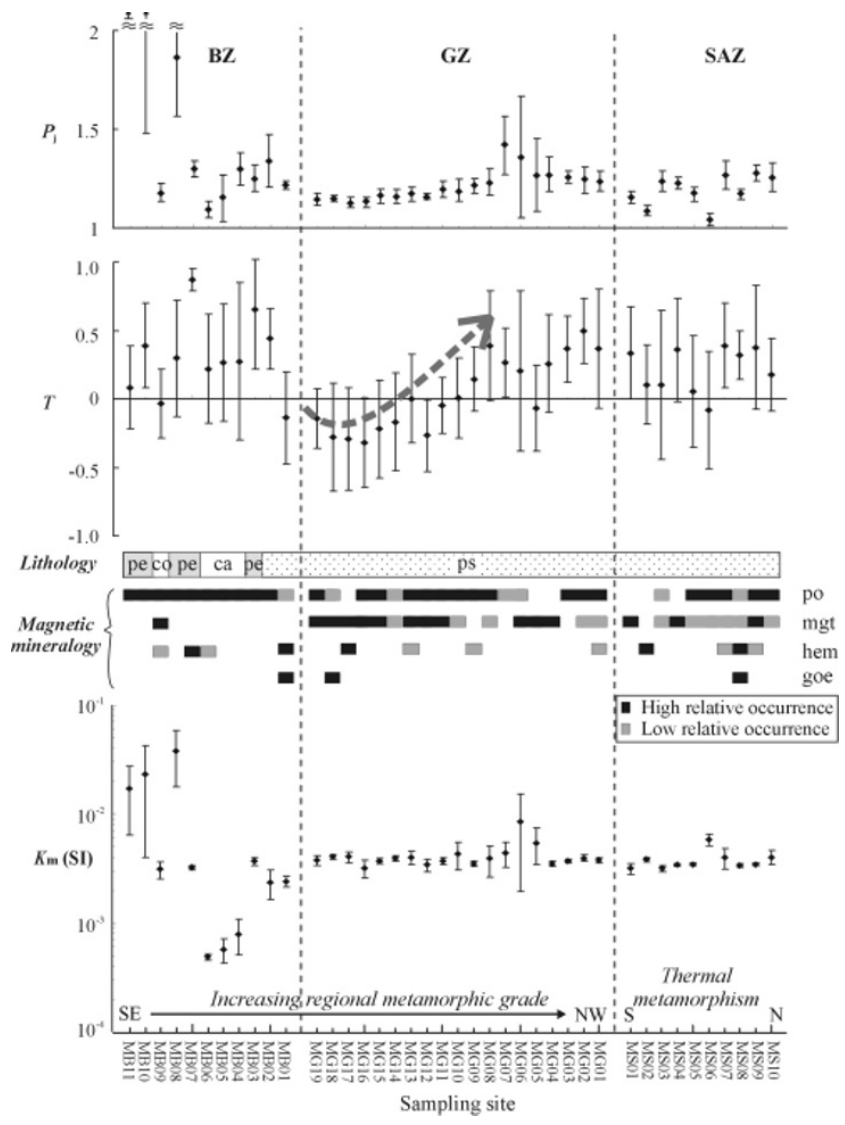

Fig. 11. Synthetic plots of sampling sites versus $P_{j}, T$, lithology, magnetic mineralogy, and $K_{m}$ values. BZ: biotite zone; GZ: garnet zone; SAZ: sillimanite + andalusite zone; pe: meta-pelite; co: meta-conglomerate; ca: meta-carbonate; ps: meta-psammite; po: pyrrhotite; mgt: magnetite; hem: hematite; goe: goethite. A dashed arrow denotes the general trend of $T$ values of meta-psammitic rocks in the southeastern and middle parts of the garnet zone.

$(T \approx 0)$ and oblate $(T>0)$ fabrics in the middle and northwestern parts of the garnet zone (Fig. 11) can be referred to the increasing contribution of pyrrhotite, based on the interpretation that both magnetite and pyrrhotite are of metamorphic in origin. It postulates that the middle and northwestern parts of the garnet zone were not in an appropriate redox condition for the transformation of pyrrhotite into magnetite although the P-T condition was sufficiently high (Bina and Daly, 1994).

\subsection{AMS fabrics, regional metamorphism, and tec- tonic model}

Evolutions of AMS fabrics in the foreland and fold/thrust belts (Atlas, Pyrenees, and Apennines) have been demonstrated by several authors (e.g., Averbuch et al., 1992; Sagnotti et al., 1998; Parés et al., 1999; Frizon de Lamotte et al., 2002; Saint-Bezar et al., 2002). Most of the previous AMS studies are, however, concerning sedimentary rocks from the external zone of fold and thrust belt, a transition zone between an apparently undeformed foreland and a highly deformed and metamorphosed domain. The majority of the magnetic fabrics encountered in such geologic settings is between sedimentary and tectonic fabrics: the magnetic foliations normal to the bedding or shortening direction and the magnetic lineations parallel to the intersec- tion direction. The development of such fabrics is associated with the pure shear in rocks accompanied with pressure solution and crystallization of ferromagnetic minerals in cracks. In some limited zone, such as fault zones, magnetic lineation was assumed to reflect the transport lineation.

Because the rocks in the study area underwent intermediate $\mathrm{P} / \mathrm{T}$ type regional metamorphism which resulted in the significant change of mineralogy in rocks, on the contrary to the above context, the magnetic fabrics observed in this study cannot be readily explained. Instead, changes in magnetic mineralogy can be invaluably utilized in interpreting the magnetic fabrics in the study area. Most AMS ellipsoids are oblate in the biotite zone, representing mineral foliation of metasedimentary rocks. The magnetic foliations of the biotite zone, recorded mainly by metamorphic pyrrhotites, may also represent the preferred orientation of phyllosilicates because the clustering of $K_{\min }$ axes is normal to cleavage plane (Fig. 8). It is interpreted that these metamorphic pyrrhotites were formed by breakdown of pyrite or detrital magnetite during the regional metamorphism and aligned with a certain preferred crystallographic orientation, reflecting the prevailing stress condition at the time of nucleation, or with a strain-induced polycrystalline grain-alignment after the crystallization. Magnetic foliations dipping to the northwest in the biotite zone agree relatively well with penetrative $S_{1}$ foliations (slaty cleavage) (Fig. 8). Such concurrence of northeast-southwest trending magnetic and structural foliations may reflect a northwest-southeast compressional regime during the prograde regional metamorphism $\left(M_{1}\right)$ in the study area.

It is noteworthy describing the magnetic lineation oriented toward down-dip direction of cleavage dipping to the west (Fig. 8), though only observed in one site (MB01) located in structurally upper unit of the thrust faults in the biotite zone (Fig. 2(a)). Kang and Lee (2002) observed mesoscopic and microscopic strain markers such as asymmetric isoclinal fold and C-S structures, indicating the eastward or southeastward shear sense associated with the thrusts in the biotite zone. The magnetic lineation observed in site MB01 probably denotes the east- and upward transport fabric, not the west- and downward one, related to the thrusting based on the strain markers. It is interpreted that this magnetic lineation in the structurally upper unit (Pibanryeong unit in Fig. 2(a)) was recorded by top-to-the-southeast vergent thrusting during regional metamorphism, and that its eastward direction was possibly due to later strike-slip fault movement around site MB01 (Fig. 8). On the other hand, most sites located in the structurally lower unit (Boeun unit in Fig. 2(b)) do not show the down-dip magnetic lineation related to the thrusting, except for three sites of MB03, 10, and 11 (Fig. 8).

In the garnet zone, samples with prolate shape of AMS ellipsoids are frequently observed (Figs. 7 and 11) and preferred orientation distributions of principal susceptibility axes dominantly reflect magnetic lineations on the basis of the clustering of $K_{\max }$ axes within the cleavage plane (Fig. 9). Magnetic lineation directions in the southeastern part (sites MG13 MG19) of the garnet zone are plunging nearly along the down-dip of the northeast-striking vertical 

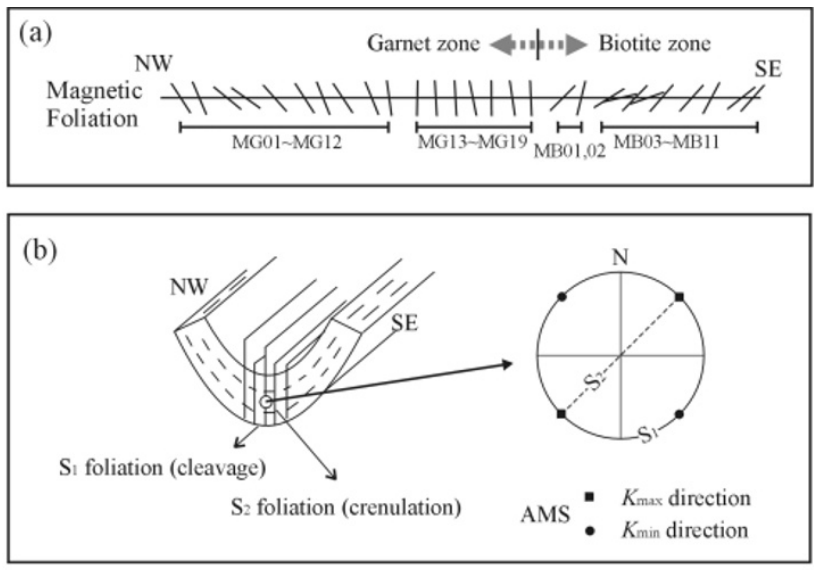

(c)
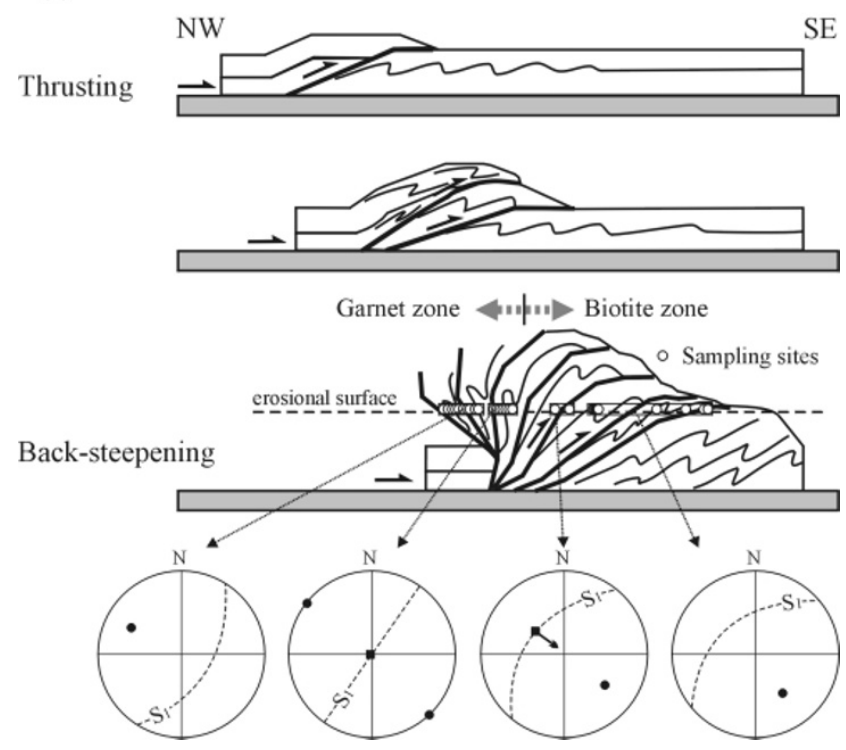

Fig. 12. (a) Attitudes and dips of the magnetic foliations observed in the study area. (b) A sketch showing the relation between the $S_{1}$ foliation (cleavage) and $S_{2}$ foliation (crenulation) in the simple synform system. A stereoplot for the expected AMS fabrics and structural foliations at the hinge of synform system is also shown. (c) Schematic presentation of development sequences of petrofabrics during $M_{1}$ regional metamorphism in the study area (modified from figure 19 of Koh and Kim, 1995). Stereoplots for the expected AMS fabrics and structural foliations across the garnet and biotite zones of back-steepening model are shown.

cleavage plane which is also normal to the $K_{\min }$ axes reflecting the magnetic foliation. In the middle and northwestern parts of the garnet zone (MG01 MG12), most magnetic lineation directions are generally plunging to the southeast, coincident with the mineral stretching lineations $\left(L_{1}\right.$ in the garnet zone of Fig. 2(c)) on the cleavage plane dipping to the southeast.

Changes in attitude, especially dip directions, of magnetic foliations observed in this study are rather systematic: southeast-dipping foliations in the northwestern part of the garnet zone through almost vertical magnetic foliations in the southeastern part of the garnet zone to northwestdipping foliations in the biotite zone (Fig. 12(a)). Several plausible kinematic models best describing the results are examined.

Magnetic foliations subparallel to the cleavage plane are frequently observed in the garnet zone (e.g., sites MG04,
$08,09,13,14,15,18$, and 19) in addition to the magnetic lineation. The vertical magnetic foliation and cleavage planes parallel to the thrust faults, as observed in the southeastern part of the garnet zone, can be developed in the frontal area of the fault-propagation fold system (e.g., Averbuch et al., 1992). However, the southeast-dipping magnetic foliations and cleavages are opposite to those (i.e., northwest-dipping magnetic foliations) expected from the structurally upper unit of the thrust system. Thus, the faultpropagation fold system cannot explain magnetic fabrics observed in this study.

Intuitively, a kilometer scale northeast-trending synform with subhorizontal fold axis, formed after development of cleavages, might explain the opposite sense of dip directions between the northern garnet zone (southeast dipping) and the biotite zone (northwest dipping) (Fig. 12(a)). To fulfill the assumption of synform system, the central area (southeastern part of the garnet zone) should show subhorizontal $S_{1}$ foliations and/or vertical $S_{2}$ crenulation foliations (Fig. 12(b)). However, vertical magnetic foliations in the southeastern part of the garnet zone clearly reflect the $S_{1}$ foliations, not the $S_{2}$ crenulation foliations (Fig. 9). Thus another explanation is obviously required.

Systematic variation of dip direction and angle, identified by our AMS fabric data, in the biotite and garnet zones is consistent with the tectonic framework proposed by Koh and Kim (1995, Goesan area of Fig. 1(b)) in which the southeast-dipping of regional foliation was due to the back-steepening process as a result of passive rotation and translation during the propagation of the thrust system (Fig. 12(c)). This explanation can be supported by the spatial distribution of magnetite occurrence because the southeastern part of the garnet zone, showing the vertical foliations, might experience more oxidizing condition (i.e., shallower depth in the antiformal stacking thrust system) appropriate for the breakdown of pyrrhotite into magnetite. The present study also shows that the magnetic foliation is a dominant fabric in the structurally lower unit (Boeun unit) of the thrust, while the magnetic lineation prevails in the structurally upper unit (Pibanryeong unit) except for the thermally metamorphosed area (sillimanite + andalusite zone) (Figs. 2, 8, 9, and 10). These observations are readily explained by the back-steepening thrust model in a way that the development of petrofabrics in the structurally upper and lower units during the thrusting is as follows: the formation of transport or stretching lineations due to the tectonic movement of the upper unit is followed by the development of foliations caused by subhorizontal compression and tectonic overburdening in the lower unit (Fig. 12(c)). The attitudes of $S_{1}$ foliation and the magnetic fabrics expected at each area in the context of the back-steepening thrust model (Fig. 12(c)) show a good agreement with those observed in this AMS study (Figs. 8, 9, and 10). Therefore, it is interpreted that the magnetic fabric (lineation) in the biotite and garnet zones was formed by the top-to-thesoutheast vergent thrust movement, and subsequently the back-steepening process in the northwestern part resulted in the formation of foliation, during the $M_{1}$ prograde regional metamorphism in the late Carboniferous to early Permian. 
Acknowledgments. This work was supported by grant No. R012000-000-00062-0 from the Korea Science \& Engineering Foundation. We would like to thank Professor Philippe Robion and Dr. Toshiya Kanamatsu for their constructive and careful reviews. Professor Hidefumi Tanaka is gratefully acknowledged for his helpful suggestion and editing the manuscript.

\section{References}

Averbuch, O., D. Frizon de Lamotte, and C. Kissel, Magnetic fabric as a structural indicator of the deformation path within a fold thrust structure: a test case from the Corbières (NE Pyrenees, France), J. Struct. Geol., 14, 461-474, 1992.

Bina, M. and L. Daly, Mineralogical change and self-reversed magnetizations in pyrrhotite resulting from partial oxidation: geophysical implications, Phys. Earth Planet. Inter., 85, 83-99, 1994.

Bina, M., J. Corpel, L. Daly, and N. Debeglia, Transformation of pyrrhotite to magnetite by heating: a potential source of magnetic anomalies, $C$. $r$. Acad. Sci., Ser. II, 313, 487-494, 1991.

Borradaile, G. J., Magnetic susceptibility, petrofabrics and strain, Tectonophysics, 156, 1-20, 1988 .

Borradaile, G. J. and B. Henry, Tectonic applications of magnetic susceptibility and its anisotropy, Earth Sci. Rev., 42, 49-93, 1997.

Borradaile, G. J., A. MacKenzie, and E. Jensen, Silicate versus trace mineral susceptibility in metamorphic rocks, J. Geophys. Res., 95, 84478451, 1990.

Butler, R. F., Palaeomagnetism: Magnetic Domains to Geologic Terranes, 319 pp., Blackwell Scientific Publications, Boston, 1992.

Cheong, C. S., K. Y. Cheong, H. Kim, M. S. Choi, S. Lee, and M. Cho, Early Permian peak metamorphism recorded in U-Pb system of black slates from the Ogcheon metamorphic belt, South Korea, and its tectonic implication, Chem. Geol., 193, 81-92, 2003.

Cho, M. and H. Kim, Metamorphic Evolution of the Ogcheon Metamorphic Belt: Review of Recent Studies and Remaining Problems, Jour. Petrol. Soc. Korea, 11, 121-137, 2002.

Chough, S. K., S.-T. Kwon, J.-H. Ree, and D. K. Choi, Tectonic and sedimentary evolution of the Korean peninsula: a review and new view, Earth Sci. Rev., 52, 175-235, 2000.

Cluzel, D., Formation and tectonic evolution of early Mesozoic intramontane basins in the Ogcheon belt (South Korea): a reappraisal of the Jurassic "Daebo orogeny", J. Southeast Asian Earth Sci., 7, 223-235, 1992.

Cluzel, D., J. P. Cadet, and H. Lapierre, Geodynamics of the Okcheon Belt (South Korea), Tectonophysics, 183, 41-56, 1990.

Cluzel, D., L. Jolivet, and J.-P. Cadet, Early Middle Paleozoic intraplate orogeny in the Okcheon belt (South Korea): a new insight on the Paleozoic buildup of East Asia, Tectonics, 10, 1130-1151, 1991.

Evans, M. A., M. T. Lewchuk, and R. D. Elmore, Strain partitioning of deformation mechanisms in limestones: examining the relationship of strain and anisotropy of magnetic susceptibility (AMS), J. Struct. Geol., 25, 1525-1549, 2003.

Ferry, J. M., Petrology of graphitic sulfide-rich schists from south-central Main: an example of desulfidation during prograde regional metamorphism, Am. Mineral, 66, 171-269, 1981.

Frizon de Lamotte, D., C. Souque, S. Grelaud, and P. Robion, Early record of tectonic magnetic fabric during inversion of a sedimentary basin: Short review and examples from the Corbiéres transfer zone (France), Bull. Soc. Geol. France, 173, 461-463, 2002.

Fuller, M. D., Magnetic anisotropy and paleomagnetism, J. Geophys. Res., 68, 293-309, 1963.

Graham, J. W., Magnetic anisotropy, an unexploited petrofabric element, Geol. Soc. Am. Bull., 65, 1257-1258, 1954.

Grégoire, V., M. Saint Blanquat, A. Nédélec, and J.-L. Bouchez, Shape anisotropy versus magnetic interactions of magnetite grains: experiments and application to AMS in granitic rocks, Geophys. Res. Lett., 22, 2765-2763, 1995.

Hargraves, R. B., D. Johnson, and C. Y. Chan, Distribution anisotropy: The cause of AMS in igneous rocks?, Geophys. Res. Lett., 18, 2193-2196, 1991.

Hrouda, F., Magnetic anisotropy of rocks and its application in geology and geophysics, Geophys. Surv., 5, 37-82, 1982.

Jelinek, V., Characterization of the magnetic fabric of rocks, Tectonophysics, 79, 63-67, 1981 .
Kanamatsu, T., E. Herrero-Bervera, and A. Taira, Magnetic fabrics of soft-sediment folded strata within a Neogene accretionary complex, the Miura group, central Japan, Earth Planet. Sci. Lett., 187, 333-343, 2001.

Kang, J. H. and C. G. Lee, Geological Structure of Okcheon Metamorphic Zone in the Miwon-Boeun area, Korea, Jour. Petrol. Soc. Korea, 11, 234-249, 2002.

Kim, H. and M. Cho, Polymetamorphism of Ogcheon Supergroup in the Miwon area, central Ogcheon metamorphic belt, South Korea, Geosciences Journal, 3, 151-162, 1999.

Kim, O. J., D. S. Lee, and H. Y. Lee, Explanatory text of the 1:50,000 geologic map of Boeun sheet, 35 pp., Korea Research Institute of Geoscience and Mineral Resource, 1977.

Kim, S. W., T. Itaya, H. Hyodo, and T. Matsuda, Metamorphic K-feldspar in low-grade metasediments from the Ogcheon metamorphic belt in South Korea, Gondwana Res., 5, 849-855, 2002.

Koh, H. J. and J. H. Kim, Deformation sequence and characteristics of the Okcheon Supergroup in the Goesan area, central Okcheon Belt, Korea, J. Geol. Soc. Korea, 31, 271-298, 1995.

Lee, C. H., M. S. Lee, and B. S. Park, Explanatory text of the 1:50,000 geologic map of Miweon sheet, 29 pp., Korea Research Institute of Geoscience and Mineral Resource, 1980.

Lee, K. S., H. W. Chang, and K. H. Park, Neoproterozoic bimodal volcanism in the central Ogcheon belt, Korea: age and tectonic implication, Precambrian Research, 89, 47-57, 1998.

Lowrie, W., Identification of ferromagnetic minerals in a rock by coercivity and unblocking temperature properties, Geophys. Res. Lett., 17, 159$162,1990$.

Oh, C. W., Y. W. Kwon, and S. W. Kim, Metamorphic Evolution of the central Okcheon Metamorphic Belt in the Cheongju-Miwon area, Korea. Jour. Petrol. Soc. Korea, 8, 106-123, 1999.

Oh, C. W., S. W. Kim, I. C. Ryu, T. Okada, H. Hyodo, and T. Itaya, Tectono-metamorphic evolution of the Okcheon Metamorphic Belt, South Korea: Tectonic implications in East Asia, Island Arc, 13, 387402, 2004.

Parés, J. P., B. A. van der Pluijm, and J. Dinarès-Turell, Evolution of magnetic fabric during incipient deformation of mudrocks (Pyrenees, Northern Spain), Tectonophysics, 307, 1-14, 1999.

Ree, J.-H., S.-H. Kwon, Y. Park, S.-T. Kwon, and S.-H. Park, Pretectonic and posttectonic emplacements of the granitoids in the south central Okchon belt, South Korea: Implications for the timing of strike-slip shearing and thrusting, Tectonics, 20, 850-867, 2001.

Robion, P., D. Frizon de Lamotte, C. Kissel, and C. Aubourg, Tectonic versus mineralogical contribution to the magnetic fabrics of epimetamorphic slaty rocks: an example from the Ardennes Massif (FranceBelgium), J. Struct. Geol., 17, 1111-1124, 1995.

Robion, P., C. Kissel, D. Frizon de Lamotte, J. P. Lorand, J. C. Guézou, Magnetic mineralogy and metamorphic zonation in the Ardennes Massif (France-Belgium), Tectonophysics, 271, 231-248, 1997.

Rochette, P., Metamorphic control of the magnetic mineralogy of the black shales in the Swiss Alps: toward the use of 'magnetic isogrades', Earth Planet. Sci. Lett., 84, 446-456. 1987.

Rochette, P., J. Jackson, and C. Aubourg, Rock magnetism and the interpretation of anisotropy of magnetic susceptibility, Rev. Geophys., 30, 209-234, 1992.

Rochette, P., J.-P. Lorand, G. Fillion, and V. Sautter, Pyrrhotite and the remanent magnetization of SNC meteorites: a changing perspective on Martian magnetism, Earth Planet. Sci. Lett., 190, 1-12, 2001.

Sagnotti, A., F. Speranza, A. Winkler, M. Mattei, and R. Funiciello, Magnetic fabric of clay sediments from the external northern Apennines (Italy), Phys. Earth. Planet. Inter., 105, 73-93, 1998.

Saint-Bezar, B., R. L. Hebert, C. Aubourg, P. Robion, R. Swennen, and D. Frizon de Lamotte, Magnetic fabric and petrographic investigation of hematite-bearing sandstones within ramp-related folds: examples from the South Atlas From (Morocco), J. Struct. Geol., 24, 1507-1520, 2002.

Stephenson, A., Distribution anisotropy: two simple models for magnetic lineation and foliation, Phys. Earth Planet. Inter., 82, 49-53, 1993.

Tarling, D. J. and F. Hrouda, The Magnetic Anisotropy of Rocks, 217 pp., Chapman and Hall, London, 1993.

Y.-H. Park, S.-J. Doh (e-mail: sjdoh@korea.ac.kr), W. Kim, and D. Suk 